Atmos. Chem. Phys., 10, 7017-7039, 2010

www.atmos-chem-phys.net/10/7017/2010/

doi:10.5194/acp-10-7017-2010

(C) Author(s) 2010. CC Attribution 3.0 License.

\title{
Historical (1850-2000) gridded anthropogenic and biomass burning emissions of reactive gases and aerosols: methodology and application
}

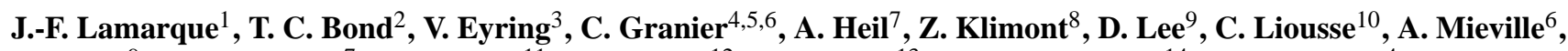 \\ B. Owen ${ }^{9}$, M. G. Schultz ${ }^{7}$, D. Shindell ${ }^{11}$, S. J. Smith ${ }^{12}$, E. Stehfest ${ }^{13}$, J. Van Aardenne ${ }^{14}$, O. R. Cooper ${ }^{4}$, \\ M. Kainuma ${ }^{15}$, N. Mahowald ${ }^{16}$, J. R. McConnell ${ }^{17}$, V. Naik ${ }^{18}$, K. Riahi ${ }^{8}$, and D. P. van Vuuren ${ }^{13}$ \\ ${ }^{1}$ National Center for Atmospheric Research, Boulder, USA \\ ${ }^{2}$ University of Illinois, Urbana-Champaign, IL, USA \\ ${ }^{3}$ Deutsches Zentrum fuer Luft- und Raumfahrt (DLR), Institut für Physik der Atmosphäre, Oberpfaffenhoffen, Germany \\ ${ }^{4}$ NOAA Earth System Research Laboratory, Chemical Sciences Division, Boulder, CO, USA \\ ${ }^{5}$ Cooperative Institute for Research in Environmental Sciences, University of Colorado, Boulder, Colorado, USA \\ ${ }^{6}$ UPMC Univ. Paris 06; CNRS/INSU, UMR 8190 LATMOS-IPSL, Paris, France, France \\ ${ }^{7}$ Forschungszentrum, Jülich, Germany \\ ${ }^{8}$ International Institute for Applied Systems Analysis, Laxenburg, Austria \\ ${ }^{9}$ Manchester Metropolitan University, Manchester, UK \\ ${ }^{10}$ Laboratoire d'Aérologie, Toulouse, France \\ ${ }^{11}$ Goddard Institute for Space Studies, National Aeronautics and Space Agency, New York, NY, USA \\ ${ }^{12}$ Joint Global Change Research Institute, Pacific Northwest National Laboratory, College Park, MD, USA \\ ${ }^{13}$ Netherlands Environmental Assessment Agency, Bilthoven, The Netherlands \\ ${ }^{14}$ European Commission, DG, Joint Research Center, Ispra, Italy \\ ${ }^{15}$ National Institute of Environmental Studies, Tsukuba, Japan \\ ${ }^{16}$ Cornell University, Ithaca, New York, USA \\ ${ }^{17}$ Desert Research Institute, Reno, Nevada, USA \\ ${ }^{18}$ High Performance Technologies Inc./NOAA Geophysical Fluid Dynamics Laboratory, Princeton, NJ, USA
}

Received: 25 January 2010 - Published in Atmos. Chem. Phys. Discuss.: 19 February 2010

Revised: 7 July 2010 - Accepted: 9 July 2010 - Published: 3 August 2010

\begin{abstract}
We present and discuss a new dataset of gridded emissions covering the historical period (1850-2000) in decadal increments at a horizontal resolution of $0.5^{\circ}$ in latitude and longitude. The primary purpose of this inventory is to provide consistent gridded emissions of reactive gases and aerosols for use in chemistry model simulations needed by climate models for the Climate Model Intercomparison Program \#5 (CMIP5) in support of the Intergovernmental Panel
\end{abstract}

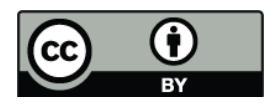

Correspondence to: J.-F. Lamarque (lamar@ucar.edu) on Climate Change (IPCC) Fifth Assessment report (AR5). Our best estimate for the year 2000 inventory represents a combination of existing regional and global inventories to capture the best information available at this point; 40 regions and 12 sectors are used to combine the various sources. The historical reconstruction of each emitted compound, for each region and sector, is then forced to agree with our 2000 estimate, ensuring continuity between past and 2000 emissions. Simulations from two chemistry-climate models are used to test the ability of the emission dataset described here to capture long-term changes in atmospheric ozone, carbon monoxide and aerosol distributions. The simulated

Published by Copernicus Publications on behalf of the European Geosciences Union. 
long-term change in the Northern mid-latitudes surface and mid-troposphere ozone is not quite as rapid as observed. However, stations outside this latitude band show much better agreement in both present-day and long-term trend. The model simulations indicate that the concentration of carbon monoxide is underestimated at the Mace Head station; however, the long-term trend over the limited observational period seems to be reasonably well captured. The simulated sulfate and black carbon deposition over Greenland is in very good agreement with the ice-core observations spanning the simulation period. Finally, aerosol optical depth and additional aerosol diagnostics are shown to be in good agreement with previously published estimates and observations.

\section{Introduction}

In order to perform climate simulations over the historical record, it is necessary to provide climate models with information on the evolution of radiatively active gases and aerosols. In particular, tropospheric ozone and aerosols of anthropogenic and biomass burning origins (sulfate, nitrate, black carbon and organic carbon) constitute the species of interest in our study. Climate models that will contribute to scenario analysis for IPCC AR5 report (Intergovernmental Panel on Climate Change; Fifth Assessment Report) usually start their model calculations in pre-industrial times, specified in this case as being 1850 (Taylor et al., 2009). As will be identified later in our study, it is however clear that anthropogenic emissions were already significantly present in 1850 . In order to enable climate model simulations, knowledge of the evolution of the necessary emissions between 1850 and 2000 is required. And it is the purpose of this study to discuss the definition of such an emission data set, based on the combination of new and existing efforts. It is important to note that the data set discussed in this study is primarily developed for defining the distribution and time evolution of short-lived climate forcing agents and not for regional air quality models.

Examples of gridded emissions can be found at the GEIA/ACCENT emissions portal (available at: http:// geiacenter.org). The determination of these emissions require a variety of steps involving the knowledge of the source of emission (e.g. amount of fossil fuel combusted by power plants), an emission factor (e.g. how much of a given chemical species is emitted for a specific mass of a given fuel burned in a specific technological process accounting for the operation of abatement measures) and a procedure for mapping onto a geographical grid (e.g. the location point sources such as power plants). As discussed in Klimont and Streets (2007) the quality of available emission inventories varies, between high quality inventories for point sources in Europe or North America (e.g. $\mathrm{SO}_{2}$ from power plants which is based on emission monitoring) and inventories that are less reliable, especially in developing or industrializing coun- tries due to incompleteness of activity data or lack of testbased emission factors. The resulting uncertainty leads to a range of possible emissions for a given process and base year that varies strongly between regions, sectors, and pollutants (e.g. Streets et al., 2006; Klimont and Streets, 2007; Bond et al., 2007). These uncertainties lead to a range of possible emission outcomes for a given source. While this issue applies to all types of emissions, we will focus in this paper on anthropogenic (defined here as originating from energy use in stationary and mobile sources, industrial processes, domestic and agricultural activities) and open biomass burning emissions. Our overall approach to building this new emission dataset is to combine a variety of data sources to maximize the information content; this is done through a combination of (1) regional and global inventories in order to define year 2000 emissions and (2) long-term global emission datasets to define historical changes in emissions.

In order to perform chemistry simulations with enough resolution to resolve regional structures and their changes, our target is to provide monthly emissions at a horizontal resolution of $0.5^{\circ}$ in latitude and longitude every 10 years. All anthropogenic and biomass burning emissions necessary for the simulation of tropospheric ozone and aerosols are provided, including methane $\left(\mathrm{CH}_{4}\right)$, carbon monoxide $(\mathrm{CO})$, nitrogen oxides $\left(\mathrm{NO}_{\mathrm{x}}\right)$, total and speciated non-methane volatile organic compounds (NMVOCs), ammonia $\left(\mathrm{NH}_{3}\right)$, organic carbon (OC), black carbon (BC) and sulfur dioxide $\left(\mathrm{SO}_{2}\right)$. Compounds relevant for other issues (e.g. CFCs, HCFCs and HFCs, mercury, persistent organic pollutants) have not been included in this inventory as they were not necessary for the stated goal of providing climate models distributions of tropospheric ozone and aerosols for radiative forcing. While interannual changes may be important for the detailed analysis of past "rapid" (i.e. less than a few years) pollution changes, we decided that decadal data are overall better suited to fulfill the needs of AR5 for the following reasons: (1) annual data sets exist only for a limited set of species (Smith et al., 2004) or only for the recent past - for example RETRO, available for the 1960-2000 period (Schultz et al., 2007, 2008) and REAS, which covers the 1980-2003 (Ohara et al., 2007; Smith et al., 2004) and (2) future emissions generated by Integrated Assessment Models (IAMs) are usually available with time steps on the order of 10 years.

Gridding follows the sectoral grids generated for EDGARv4 (EC-JRC/PBL, 2009), averaged from its original $0.1^{\circ}$ resolution to our nominal $0.5^{\circ}$ grid. While this is clearly adequate for present-day, such gridding will not be representative of older emission distributions. We are therefore performing two separate griddings: one from EDGAR$\mathrm{v} 4$, the other based solely on population (Goldewijk, 2005). The final gridding is a linear combination of both, with the EDGAR-v4 component linearly increasing in time after 1900 to 1980, after which the EDGAR-v4 grids are used. 
Table 1. List of multi-decadal inventories used in this study.

\begin{tabular}{lccccc}
\hline & $\begin{array}{c}\text { EDGAR-HYDE } \\
\text { EDGAR }\end{array}$ & RETRO & Smith et al. & Bond et al. & $\begin{array}{c}\text { Junker and } \\
\text { Liousse }\end{array}$ \\
\hline Species & $1890-2000$ & $1960-2000$ & $1850-2000$ & $1850-2000$ & $1860-1997$ \\
\hline $\mathrm{CH}_{4}$ & $\mathrm{X}$ & & & & \\
$\mathrm{CO}$ & $\mathrm{X}$ & $\mathrm{X}$ & & & \\
$\mathrm{NO}_{\mathrm{x}}$ & $\mathrm{X}$ & $\mathrm{X}$ & & & \\
$\mathrm{NMVOC}$ & $\mathrm{X}$ & $\mathrm{X}$ & & & \\
$\mathrm{NH}_{3}$ & $\mathrm{X}$ & & $\mathrm{X}$ & & \\
$\mathrm{SO}_{2}$ & & & & $\mathrm{X}$ & $\mathrm{X}$ \\
$\mathrm{OC}$ & & & & $\mathrm{X}$ & $\mathrm{X}$ \\
$\mathrm{BC}$ & & & & & \\
\hline
\end{tabular}

Finally, we have decided to include seasonal variations (at the monthly scale) for biomass burning, soil $\mathrm{NO}_{\mathrm{x}}$, ship and aircraft emissions only. Other emissions, while gridded on a monthly basis, have constant values for each month. We have indeed considered that there as insufficient information available (especially for past emissions) on the seasonality to impose a temporal profile; we therefore prefer the end-user to assign such a seasonal variation if preferred.

The paper is organized as follows: in Sect. 2, we discuss the land-based anthropogenic emissions, defined here as originating from industrial, domestic and agriculture activity sectors. Section 3 described the biomass burning emissions. In Sect. 4, we present our reconstruction of ship and aircraft emissions. Application of these emissions in chemistryclimate models and the analysis of the modeled concentrations of ozone carbon monoxide and aerosols are discussed in Sect. 5. Finally, discussion and conclusions are in Sect. 6.

\section{Land-based anthropogenic emissions}

In the case of land-based anthropogenic emissions (i.e., excluding aircraft and ship emissions), two available datasets on historical emissions, RETRO (1960-2000; Schultz et al., 2007) and EDGAR-HYDE (1890-1990; van Aardenne et al., 2001), provide information on emission changes over the second half of the 20th century for a limited set of compounds (Table 1). As mentioned in the Introduction, our approach consists of generating first our best estimate for 2000, based on the combination of global and regional datasets. This aggregation is performed using a set of 40 regions (Table 2) and 12 sectors (Table 3). Then, using a combination of RETRO and EDGAR-HYDE, historical trends for each sector in each region are generated. Finally, the historical emissions of reactive gases (ozone precursors only) are computed using the historical trends applied to our 2000 emissions. We discuss those three steps in this section.
Table 2. List of regions.

\begin{tabular}{cl}
\hline Region number & Name of Region \\
\hline 1 & Canada \\
2 & USA \\
3 & Mexico \\
4 & Rest of Central America \\
5 & Brazil \\
6 & Venezuela \\
7 & Argentina \\
8 & Rest of South America \\
9 & Northern Africa \\
10 & Western Africa \\
11 & Eastern Africa \\
12 & Rest of Southern Africa \\
13 & South Africa \\
14 & France \\
15 & Germany \\
16 & Italy \\
17 & UK \\
18 & Rest of Western Europe \\
19 & Rest of Central Europe \\
20 & Baltic States (Estonia, Latvia, Lithuania) \\
21 & Turkey \\
22 & Ukraine \\
23 & Kazachstan region \\
24 & Russia \\
25 & Middle East \\
26 & India \\
27 & Rest of South Asia \\
28 & South Korea (Republic of Korea) \\
29 & North Korea (Democratic People's Republic of Korea) \\
30 & China \\
31 & Taiwan \\
32 & Thailand \\
33 & Rest of Southeastern Asia \\
34 & Indonesia \\
35 & Japan \\
36 & Australia \\
37 & New Zealand \\
38 & Rest of Oceania \\
39 & Greenland \\
40 & Antarctica \\
\hline &
\end{tabular}


Table 3. List of sectors.

\begin{tabular}{cl}
\hline Sector number & Sector name \\
\hline 1 & Energy production and distribution \\
2 & Industry (combustion and non-combustion) \\
3 & Land transport \\
4 & Maritime transport \\
5 & Aviation \\
6 & Residential and commercial \\
7 & Solvents \\
8 & Agriculture \\
9 & Agricultural waste burning on fields \\
10 & Waste \\
11 & Open vegetation fires in forests \\
12 & Open vegetation fires in savanna and grasslands
\end{tabular}

While several recent assessments have shown that regional emissions have experienced significant changes between 2000 and present, especially in South Asia (e.g., Richter et al., 2005; Zhang et al., 2009; Klimont et al., 2009), the necessity to rapidly generate an inventory that could be used as a basis for the future projections using Integrated Assessment Models for the upcoming IPCC AR5 required that the latest year we felt we could confidently use (as of late 2008) was the year 2000. The additional information from the references cited above are taken into account in the projections for 2005 which will be discussed elsewhere.

\subsection{Definition of year 2000 emission}

Anthropogenic emissions of reactive gases in 2000 are defined in terms of a variety of global and regional inventories (Table 4). In generating our emission dataset, published or reviewed regional inventories have been given preference over global inventories where these were available. This was the case for the EMEP (2006) inventory for Europe, the REAS inventory for Asia and the EPA inventory for North America. In those regions we assume that these inventories more appropriately reflect regional circumstances than the global inventories. Furthermore, the inventories for North America and European countries within the EMEP domain have been extensively evaluated through model and observation studies. In addition, inventories reported as Annex I inventories to the United Nations Framework Convention on Climate Change (UNFCCC) are subject to expert review. The EDGARv32 FT2000 dataset (Van Aardenne et al., 2005; Olivier et al., 2005) and preliminary emissions from EDGAR v4.0 for agriculture (EC-JRC/PBL, 2009) are used where regional information is not available. A summary is given in Table 4. As the various inventories are combined at the level of regional averages, no attempt is made at smoothing potential discontinuities across regional boundaries.
Following the new sectoral definition in EDGAR-v4, we have included the contribution from biofuel combustion (for cooking and heating) in the residential sector (Table 3). Agricultural waste burning is therefore restricted to the burning of biomass left on the fields. Our global estimate for 2000 of those latter emissions are in good agreement with the published estimate of Yevich and Logan (2002).

Although additional information is available in the literature for several regions (e.g., Zhang et al., 2009; Streets et al., 2003, 2006; Klimont et al., 2009; Cofala et al., 2007; NARSTO, 2006; Garg et al., 2006), we did not attempt to include those as they were already integrated into the datasets we have used (e.g., for East Asia REAS includes results of several specific inventories) or, less frequently, were less complete than the inventories applied in this study (e.g. only covering 1 country or did not extend to the year 2000).

The specific case of regional carbon monoxide emissions is highlighted in Table 5. In this case, we see that the our emission inventory is well within the range of published estimates at the regional and global scales. Agreement for other species is found to be similar or better (not shown). Emissions of black carbon (BC) and organic carbon (OC) included in the dataset presented here (Table 4) represent an update of Bond et al. (2007) and Junker and Liousse (2008) as harmonization of emission factors was performed for the year 2000 from these papers and the studies they reference; more details are presented in the next section.

Emissions from the UNFCCC Emissions of sulfur dioxide submissions and other regional inventories were used where available (Table 4). Bottom-up estimates of emissions are used where inventory data were either unavailable or inconsistent. Details are given in Smith et al. (2010).

For all species, gridding is performed using the EDGAR v4.0 spatial distribution maps specific for each sector at a $0.1^{\circ}$ resolution, and aggregated to a $0.5^{\circ}$ grid (ECJRC/PBL, 2009). The $2000 \mathrm{SO}_{2}$ map used additional data from EDGARv32 FT2000 for smelting and fuel processing emissions.

\subsection{Historical reconstruction}

As we have two distinct long-term emission datasets for ozone precursors (RETRO and EDGAR-HYDE) with differing trends and there is no a priori reason to choose one inventory over the other, we have devised an approach that maximizes the information from both datasets where applicable. Using the RETRO and EDGAR-HYDE historical trends per region and per sector, we generate historical trends for each sector in each region by defining the ratio of the emissions at a specific decade to its value in 2000 (our reference data set). This ratio is a concise representation of the combined changes in fuel use and emission factor over time and its full history (1850-2000) that can be used to scale our 2000 inventory to define emissions in previous decades. The scaling of the anthropogenic emissions for reactive gases 
Table 4. Primary source of information for the various regional inventories used in the definition of the 2000 dataset.

\begin{tabular}{lcccc}
\hline Region & Ozone prec. & $\mathrm{SO}_{2}$ & $\mathrm{OC} / \mathrm{BC}$ & $\mathrm{NH}_{3}$ \\
\hline Asia & Cofala et al., 2007 & Smith et al., 2010 & Bond et al., 2007 & EDGAR-v4 \\
Europe & EMEP & UNFCCC & Bond et al., 2007 & EDGAR-v4 \\
United States & EPA & EPA & Bond et al., 2007 & EDGAR-v4 \\
Japan, Australia, NZ & UNFCCC & UNFCCC & Bond et al., 2007 & EDGAR-v4 \\
Canada & Env. Canada & Env. Canada & Bond et al., 2007 & EDGAR-v4 \\
Latin America & EDGAR-v4 & Smith et al., 2010 & Bond et al., 2007 & EDGAR-v4 \\
South America & EDGAR-v4 & Smith et al., 2010 & Bond et al., 2007 & EDGAR-v4 \\
Other regions & EDGAR-v4 & Smith et al., 2010 & Bond et al., 2007 & EDGAR-v4 \\
\hline
\end{tabular}

Table 5. Regional and global estimate of year 2000 CO anthropogenic and biomass burning emissions ( $\mathrm{Tg}(\mathrm{CO}) /$ year $)$. This table uses data from the following: EDGAR-FT2000: http://www.mnp.nl/edgar/model/v32ft2000edgar/docv32ft2000/;RETRO: http://retro.enes.org/pub_reports.shtml; GAINS: Cofala et al., 2007; EPA-2006: http://www.epa.gov/airtrends/2006/emissions_summary_2005.html; EMEP-2004: Vestreng et al., Technical Report NSC-W 1/2004; TRACE-P: Streets et al., 2003; GFED-v2: Randerson et al., 2005; GICC: Mieville et al., 2010.

\begin{tabular}{|c|c|c|c|c|c|c|c|}
\hline Anthro. & EDGAR-FT2000 & RETRO & GAINS & EPA-2006 & EMEP-2004 & TRACE-P & This work \\
\hline Global & 548 & 476 & 542 & N/A & N/A & N/A & 611 \\
\hline US & 74 & 56 & 75 & 102 & N/A & N/A & 93 \\
\hline W. Europe & 30 & 19 & 38 & N/A & 31 & N/A & 31 \\
\hline \multirow[t]{3}{*}{ China } & 98 & 95 & 128 & N/A & N/A & 100 & 121 \\
\hline & & Bio. burn. & GFED-v2 & GICC & This work & & \\
\hline & & Global & 427 & 467 & 459 & & \\
\hline
\end{tabular}

(excluding $\mathrm{SO}_{2}$ ) using EDGAR-HYDE and RETRO relies on the assumption that each reconstruction provides a reasonable (albeit sometimes different) representation of the time evolution of emissions; this can clearly only be applied to species available in both emission datasets, i.e. $\mathrm{CO}, \mathrm{NO}_{\mathrm{x}}$ and NMVOCs. The main differences between the RETRO and EDGAR-HYDE datasets are in the emission factors variations over time (with RETRO having more technology information) and, to a lesser extent, the completeness of the inventory (e.g. no industrial process emissions in RETRO). Therefore, emissions for decades prior to 2000 can be calculated through a direct scaling (per sector and region) of our 2000 emissions, with a weighting factor defined as a linear combination of the RETRO and EDGAR-HYDE scaling factors, increasingly favoring EDGAR-HYDE when going further back in time (as RETRO is only available from 1960). To provide emissions back to 1850, EDGAR-HYDE emissions (which cover 1890 to 1990) are extrapolated to 1850 using global fossil fuel consumption estimates from Andres et al. (1999) and regional scale data for population from the HYDE dataset (Goldewijk, 2005).
In summary, the scaling for each sector and region is computed using the following steps:

1. The 1990-2000 change is computed in RETRO only (since the year 2000 is not included in EDGAR-HYDE).

2. The decadal changes between 1960 and 1990 are a combination of RETRO and EDGAR-HYDE.

3. The decadal changes between 1890 and 1960 are computed from EDGAR-HYDE only (no RETRO estimates prior to 1960).

4. The emissions between 1850 and 1890 are exactly as computed from EDGAR-HYDE and its extrapolation.

5. Smoothing is applied to scaling factors across 1960 and 1990 to limit jumps in the scaling factor.

The advantage of using a scaling approach is that it only requires that the existing emission inventories provide a time history of the specific emission, without having to deal with emission biases between inventories. Clearly, such history is meaningful only within a particular sector and for a specific region as pollution controls vary; the scaling therefore 
Table 6. Recent trend in US emissions ( $\mathrm{Tg}$ (species)/year; NOx expressed as NO2). Data are available from: EPA-2003: http://www.epa.gov/oar/aqtrnd03/appenda.pdf;EPA--2006:http: //www.epa.gov/airtrends/2006/emissions_summary_2005.html; EDGAR-HYDE: van Aardenne et al. (2001); RETRO: http://retro.enes.org/pub_reports.shtml.

\begin{tabular}{lcccc}
\hline 1970 & CO & NOx & Total VOCs & $\mathrm{SO}_{2}$ \\
\hline EDGAR-HYDE & 84.2 & 16.6 & 19.4 & N/A \\
RETRO & 115.5 & 19.1 & $*$ & N/A \\
EPA-2003 & N/A & N/A & N/A & N/A \\
EPA-2006 & 197.3 & 26.9 & 33.7 & 31.2 \\
This work & 79.9 & 16.5 & 25.8 & 27.0 \\
& & & & \\
1980 & CO & NOx & Total VOCs & SO2 \\
EDGAR-HYDE & 90.2 & 19.0 & 22.4 & N/A \\
RETRO & 109.3 & 20.3 & $*$ & N/A \\
EPA-2003 & 105.7 & 22.0 & 23.7 & 23.3 \\
EPA-2006 & 177.8 & 27.1 & 30.1 & 25.9 \\
This work & 118.8 & 19.8 & 25.4 & 22.2 \\
& & & & \\
1990 & CO & NOx & Total VOCs & SO2 \\
EDGAR-HYDE & 95.1 & 21.8 & 24.2 & N/A \\
RETRO & 96.4 & 19.1 & $*$ & N/A \\
EPA-2003 & 89.2 & 21.8 & 18.9 & 21.3 \\
EPA-2006 & 143.6 & 25.2 & 23.1 & 23.1 \\
This work & 112.1 & 20.6 & 23.8 & 19.0 \\
& & & & \\
2000 & CO & NOx & Total VOCs & SO2 \\
EDGAR-HYDE & N/A & N/A & N/A & N/A \\
RETRO & 55.7 & 18.5 & $*$ & N/A \\
EPA-2003 & 98.4 & 22.4 & 18.3 & 16.2 \\
EPA-2006 & 102.4 & 22.3 & 16.9 & 16.3 \\
This work & 93.0 & 19.6 & 15.2 & 14.8 \\
\hline & & & &
\end{tabular}

captures the change in fuel amount (usually fairly wellconstrained) and change in the emission factors. It also relies on the assumption of an unbiased 2000 estimate; however, if such a bias were to be present, the methodology presented here could be applied to an updated set of 2000 estimates.

Results from this scaling process are illustrated in Table 6 where the generated time evolution is compared with previsouly published estimates. Because of the completeness of data available from the US EPA and the importance of those emissions, we focus our analysis on those emissions. We see that, as discussed earlier, our estimates for 2000 are in good agreement with the EPA data. The largest discrepancy occurs with the CO emissions going back to 1970 . It is however critical to note that the EPA estimates, with emissions largely driven by the transportation sector, are potentially over-estimated, based on the independent analysis of Parrish (2006). Indeed, this paper shows that the use of surface observations of CO strongly suggests an overestimate (by a factor of 2) in the EPA-2004 data (and 2006) as far back as 1970. In the Parrish paper, the CO observed trends and values seem to be in better agreement with the EPA-2003 (and older) data, and therefore in quite good agreement with our estimates. Other species have a smaller spread in their estimated emissions and our inventory is consistent with those.

While there can be wide variations for a specific sector or region, the global total amounts of anthropogenic emissions for each compound are actually quite similar to either RETRO or EDGAR-HYDE (Fig. 1 and Table 7), except for NMVOCs. The largest difference (in absolute amounts) is an increase in $\mathrm{CO}$ emissions compared to the EDGAR-HYDE estimate. Emissions of nitrogen oxides are quite similar between the two original inventories; in particular, the emissions between 1960 and 1980 are almost identical in RETRO and EDGAR-HYDE. Our combined dataset ends up slightly higher over that time period because our $2000 \mathrm{NO}_{\mathrm{x}}$ emission estimate is larger than in RETRO. On the other hand, our 2000 NMVOC emissions are smaller than either RETRO or EDGAR-HYDE, again with a peak in 1990, similar to RETRO.

For OC and BC, the inventory structure was based largely on the structure presented in Bond et al. (2004) and the timevarying technology divisions in Bond et al. (2007). New information on emission factors has become available since that time and these were incorporated. Several new studies on emission factors have become available in recent years: domestic coal burning emission factors were updated based on an extensive study in China (Chen et al., 2005, 2006; Zhi et al., 2008). Domestic biofuel now includes the laboratory reports of Venkataraman et al. (2005) and Parashar et al. (2005) and field data from Roden et al. (2006, 2007), Johnson et al. (2008); ship emission factors are now taken from Sinha et al. (2003), Lack et al. (2008) and Petzold et al. (2008). Black carbon fractions for two-stroke engines are from Volckens et al. (2008); emission factors for cement kilns are added based on the US EPA compilation of emission factors (AP-42, 1996), and black and organic carbon fractions from US EPA's SPECIATE database (2004).

We have performed a sector-by-sector comparison to resolve differences between the inventories of Bond et al. (2007) and Junker and Liousse (2008). Because of differing treatments of emission factors, black carbon emissions from fossil fuels are about twice as great in the latter inventory. The largest sectoral difference between the inventories was in power generation, where emission factors were two orders of magnitude higher in Junker and Liousse (2008). Relevant measurements were compiled and the two groups agreed on an intermediate emission factor. With the consensus emission factors, power generation contributes less than $1 \%$ of total black carbon emissions.

In addition, for all decades, emissions of $\mathrm{OC}$ and $\mathrm{BC}$ from agricultural waste burning were computed from the $\mathrm{CO}$ estimate of agricultural waste burning at each decade scaled using regional emission factor $(\mathrm{OC} / \mathrm{CO}$ and $\mathrm{BC} / \mathrm{CO})$ based on our 2000 emission estimates of $\mathrm{OC}, \mathrm{BC}$ and $\mathrm{CO}$. 

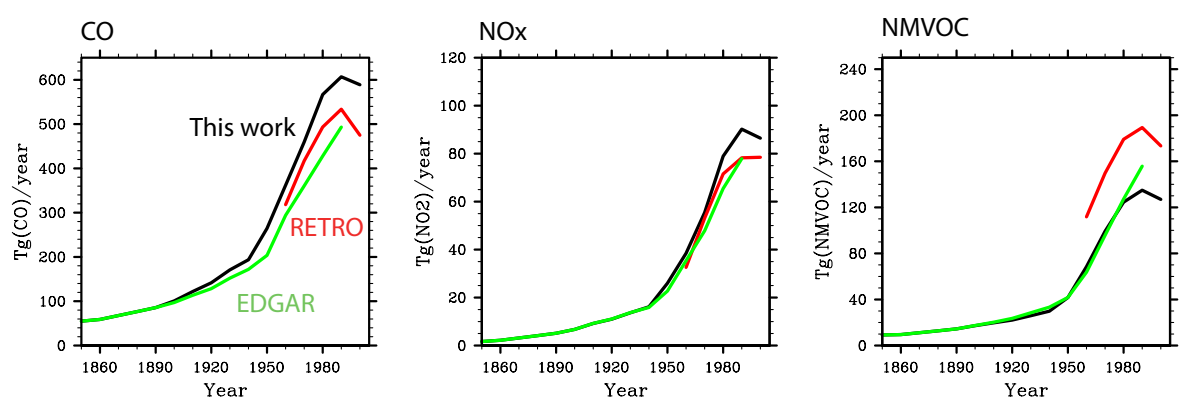

Fig. 1. Time evolution of the total (sum of all sectors but agricultural waste burning) land anthropogenic emissions for $\mathrm{CO}(\mathrm{Tg}(\mathrm{CO}) / \mathrm{year}$ ), $\mathrm{NO}_{\mathrm{X}}\left(\mathrm{Tg}\left(\mathrm{NO}_{2}\right) /\right.$ year $)$ and total NMVOC $(\mathrm{Tg}(\mathrm{NMVOC}) /$ year $)$.

Table 7. Global amounts of emission from anthropogenic sources for each species considered in this study

\begin{tabular}{cccccccc}
\hline Year & $\mathrm{CO}$ & $\mathrm{NO}_{\mathrm{x}}$ & $\mathrm{VOC}$ & $\mathrm{BC}$ & $\mathrm{OC}$ & $\mathrm{NH}_{3}$ & $\mathrm{SO}_{2}$ \\
\hline 1850 & 63.04 & 1.24 & 10.16 & 1.05 & 4.63 & 6.55 & 2.02 \\
1860 & 67.26 & 1.59 & 10.46 & 1.25 & 5.27 & 7.34 & 2.95 \\
1870 & 76.60 & 2.23 & 12.15 & 1.49 & 5.83 & 7.40 & 4.62 \\
1880 & 85.99 & 2.88 & 13.85 & 1.71 & 6.20 & 7.47 & 7.67 \\
1890 & 95.66 & 3.55 & 15.62 & 1.99 & 6.51 & 7.54 & 12.61 \\
1900 & 111.11 & 4.60 & 18.48 & 2.31 & 6.82 & 8.62 & 19.82 \\
1910 & 132.79 & 6.24 & 20.99 & 2.79 & 7.50 & 9.20 & 30.09 \\
1920 & 153.03 & 7.42 & 23.46 & 2.98 & 7.76 & 10.85 & 33.18 \\
1930 & 182.76 & 9.18 & 27.41 & 2.81 & 8.07 & 12.20 & 41.29 \\
1940 & 206.59 & 10.81 & 31.17 & 2.86 & 8.69 & 12.88 & 49.96 \\
1950 & 277.91 & 17.24 & 43.35 & 2.91 & 8.78 & 16.97 & 56.96 \\
1960 & 376.54 & 25.40 & 70.36 & 3.22 & 9.78 & 20.82 & 87.31 \\
1970 & 474.43 & 36.49 & 101.16 & 3.34 & 10.25 & 26.48 & 117.65 \\
1980 & 583.75 & 51.84 & 126.75 & 4.51 & 10.98 & 35.18 & 120.33 \\
1990 & 626.76 & 59.24 & 137.50 & 4.81 & 11.91 & 42.61 & 116.11 \\
2000 & 608.28 & 56.77 & 129.53 & 5.02 & 12.56 & 37.46 & 92.71 \\
\hline
\end{tabular}

For $\mathrm{NH}_{3}$ we use the reconstruction by Beusen et al. (2008) while for $\mathrm{CH}_{4}$, since only one historical inventory (EDGARHYDE) exists, the only constraint to the present emission dataset comes from our 2000 estimate.

Emissions of sulfur dioxide are an update of Smith et al. (2001, 2004), with emissions from the UNFCCC submissions and other regional inventories used where available. Bottom-up estimates of emissions are used where inventory data was either unavailable or inconsistent. Details are given in Smith et al. (2010).

Soil emissions of nitrogen oxides are clearly affected by the use of fertilizers; it is therefore difficult to disentangle the natural and anthropogenically-perturbed components to this flux. In the present work, the 2000 anthropogenic portion (included in the agricultural sector) is estimated in EDGAR-v4. To extend this to prior decades, we have used the EDGARHYDE estimate of soil $\mathrm{NO}_{\mathrm{x}}$ emissions prior to 1950 (i.e. before strong growth in man-made fertilizer use; Erisman et al., 2009) to define the natural component. The long-term time evolution (applied to our 2000 estimate and corrected for the natural contribution) is based on the results from Yan et al. (2005). In addition, the seasonal cycle (available at a monthly scale) is taken from the 2000 data from Yan et al. (2005) and applied to all decades.

For all ozone precursors and $\mathrm{NH}_{3}\left(\mathrm{OC} / \mathrm{BC}\right.$ and $\mathrm{SO}_{2}$ are gridded separately based on their respective previous methods), gridding of the emissions for the 1850-2000 period relies on a weighted mean of the distributions obtained using either population (from the HYDE dataset) or the year 2000 gridded emissions provided by EDGAR-v4. It is applied so that the weighting associated with the 2000 gridded distributions decreases when going back in time, with emissions after 1980 using the same grid as 2000; this is based on the assumption that, within a region, heavy infrastructure (such as power plants) has a very long (decades) lifespan. Although this approach might lead in few specific areas to shifts in source allocation (e.g., the collapse of several economies in Eastern Europe in the 1990s "removed from the map" several industrial sources), we believe this has only limited impact on the simulations intended using these historical sets of data.

No vertical emission profile is provided; however, the availability of sectoral emissions (energy, industry, domestic, etc.) in our emission files allows consistent assumptions about stack height to be applied if desired.

Speciation of NMVOC emissions is performed using the RETRO inventory. In this case, regional information for the split of the total NMVOC emitted into a set of specific hydrocarbons (Table 8) is available for the year 2000. Because of the lack of additional information, the same ratio (specific hydrocarbon to total NMVOCs at each grid point) is kept constant for the whole historical period.

\section{Biomass burning emissions}

Only a few inventories provide biomass burning emissions for the past decades (Ito and Penner, 2005; Schultz et al., 2008; Mieville et al., 2010). In this paper, we focus on the following: (1) the RETRO inventory (Schultz et al., 

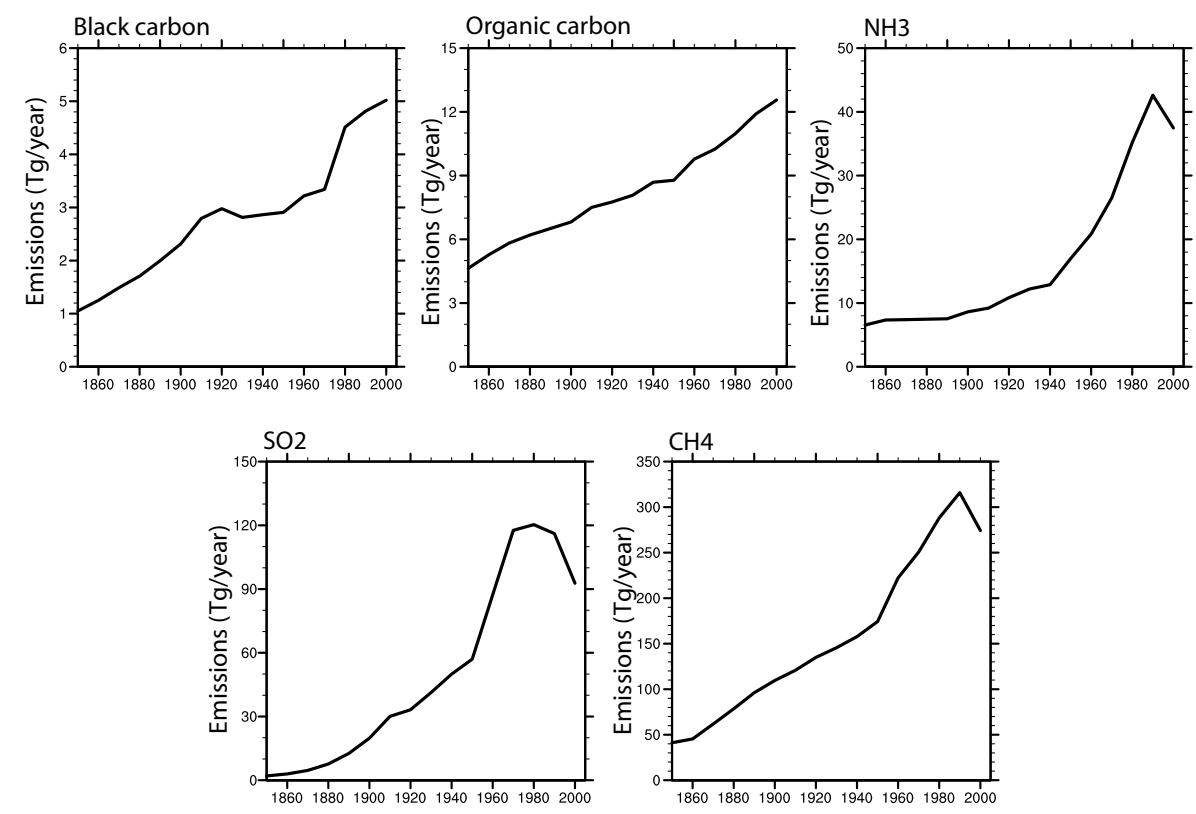

Fig. 2. Time evolution of the total (sum of all sectors) land anthropogenic emissions for black carbon $(\mathrm{Tg}(\mathrm{C}) / \mathrm{year})$, organic carbon $(\mathrm{Tg}(\mathrm{C}) /$ year $)$, ammonia $\left(\mathrm{Tg}\left(\mathrm{NH}_{3}\right) /\right.$ year), sulfur dioxide $\left(\mathrm{Tg}\left(\mathrm{SO}_{2}\right) /\right.$ year $)$, and methane $\left(\mathrm{Tg}\left(\mathrm{CH}_{4}\right) /\right.$ year $)$.

Table 8. NMVOC speciation.

\begin{tabular}{|c|c|c|}
\hline name & molecular weight & comments \\
\hline alcohols & 46.2 & assumed $\mathrm{C}_{2} \mathrm{H}_{5} \mathrm{OH}$ \\
\hline ethane & 30.0 & \\
\hline propane & 44.0 & \\
\hline butanes & 57.8 & \\
\hline pentanes & 72.0 & \\
\hline hexanes and higher & 106.8 & \\
\hline ethene & 28.0 & \\
\hline propene & 42.0 & \\
\hline ethyne & 26.0 & \\
\hline other alkenes and alkynes & 67.0 & \\
\hline benzene & 78.0 & \\
\hline toluene & 92.0 & \\
\hline xylene & 106.0 & \\
\hline trimethyl benzenes & 120.0 & \\
\hline other aromatics & 126.8 & \\
\hline esters & 104.7 & surrogate species $=\mathrm{CH}_{3} \mathrm{C}(\mathrm{O}) \mathrm{O}\left(\mathrm{CH}_{2}\right) \mathrm{nCH}_{3}$ \\
\hline ethers & 81.5 & surrogate species $=\mathrm{CH}_{3} \mathrm{CH}_{2} \mathrm{O}\left(\mathrm{CH}_{2}\right) \mathrm{nCH}_{3}$ \\
\hline chlorinates HC & 138.8 & \\
\hline methanal $\left(\mathrm{CH}_{2} \mathrm{O}\right)$ & 30.0 & \\
\hline other alkanals & 68.8 & \\
\hline ketones & 75.3 & \\
\hline acids & 59.1 & \\
\hline other VOC & 68.9 & use median $C$ ratio of other compounds \\
\hline
\end{tabular}


2008) provides emissions from wildfires for each year during the 1960-2000 period, on a monthly basis; (2) the GICC inventory (Mieville et al., 2010) gives emissions from open biomass burning for the 20th century (1900-2000) on a decadal basis based on Mouillot et al. (2005); (3) the GFEDv2 inventory (van der Werf et al., 2006) covers emissions for the 1997-2006 period.

For our study, we have established a best estimate of historic biomass burning emissions from a combination of three datasets: the GICC inventory is used as input data for the construction of the 1900-1950 dataset, the RETRO inventory for the 1960-1990 dataset and the GFEDv2 inventory for the 2000 estimate. The GFEDv2 inventory was favored over the 2000 estimate from RETRO because it is one of the most state-of-the art global biomass burning dataset currently available that incorporates satellite-based burned area estimates and seasonality.

Given the substantial interannual variability of biomass burning on a global and regional scale (e.g., Duncan et al., 2003; Schultz et al., 2008), it is problematic to use a snapshot dataset from an individual year for the development of a dataset that is considered to be representative for a decade. We therefore decided to construct historic gridded biomass burning emissions from decadal means (years 0 to 9 of a given decade), except for the 2000 estimate which is calculated from the 1997-2006 average.

In order to enforce consistency of biomass burning emissions over the entire period, carbon emission fluxes from the three datasets are first harmonized, taking the 2000 estimate from GFEDv2; emissions of trace gases and aerosols are then re-calculated from the gridded carbon emission fluxes provided in the three datasets by applying a single set of vegetation-type specific emission factors. The vegetation cover map is derived from the MODIS predominant vegetation cover map as provided with the GFEDv2 inventory (van der Werf et al., 2006). It contains a classification of the year 2000 vegetation into the major vegetation classes savanna/herbaceous vegetation, tropical forest and extratropical forest. The emission factors for these classes were harmonized to those given by Andreae and Merlet (2001, with updates from M. O. Andreae, personal communication, 2008).

Emissions from burning of soil organic matter, notably peat soil, which is ignited by fires in the overlying surface vegetation, may strongly influence emission production in some boreal and tropical regions (Page et al., 2002; Kasischke et al., 2005). Therefore, peat fires are explicitly taken into account in our inventory. We assumed that peat fires can contribute up to $45 \%$ to the total carbon emissions released per grid cell if the fractional peat cover is $100 \%$. If the fractional peat cover is lower, the relative contribution of carbon emissions from fires in surface vegetation increases accordingly. Note that this is an update from the original RETRO inventory. Information on the fractional distribution of peat soils is taken from the FAO (2003) WRB Map of World Soil Resources. The assumed maximal contribution of peat fires
Table 9. Global amounts of emission from biomass burning for each species considered in this study. $\mathrm{Tg}$ (species)/year except for $\mathrm{NO}_{\mathrm{x}}$ which is expressed as $\mathrm{Tg}(\mathrm{NO}) /$ year.

\begin{tabular}{cccccccc}
\hline Year & $\mathrm{CO}$ & $\mathrm{NO}_{\mathrm{x}}$ & $\mathrm{VOC}$ & $\mathrm{BC}$ & $\mathrm{OC}$ & $\mathrm{NH}_{3}$ & $\mathrm{SO}_{2}$ \\
\hline 1850 & 322.55 & 10.36 & 51.81 & 2.03 & 17.99 & 6.14 & 2.45 \\
1860 & 322.55 & 10.36 & 51.81 & 2.03 & 17.99 & 6.14 & 2.45 \\
1870 & 322.55 & 10.36 & 51.81 & 2.03 & 17.99 & 6.14 & 2.45 \\
1880 & 322.55 & 10.36 & 51.81 & 2.03 & 17.99 & 6.14 & 2.45 \\
1890 & 322.55 & 10.36 & 51.81 & 2.03 & 17.99 & 6.14 & 2.45 \\
1900 & 322.44 & 10.36 & 51.81 & 2.03 & 17.99 & 5.80 & 2.44 \\
1910 & 315.18 & 10.04 & 50.78 & 1.97 & 17.60 & 5.85 & 2.43 \\
1920 & 277.97 & 9.05 & 44.52 & 1.78 & 15.14 & 4.84 & 2.06 \\
1930 & 276.30 & 9.07 & 44.15 & 1.79 & 14.94 & 4.68 & 2.01 \\
1940 & 267.19 & 8.86 & 42.57 & 1.75 & 14.25 & 4.37 & 1.90 \\
1950 & 260.79 & 8.74 & 41.43 & 1.74 & 13.70 & 4.12 & 1.82 \\
1960 & 286.46 & 8.12 & 47.54 & 1.81 & 14.57 & 4.81 & 2.03 \\
1970 & 333.81 & 9.40 & 55.51 & 2.10 & 16.86 & 5.68 & 2.37 \\
1980 & 383.22 & 10.28 & 64.54 & 2.31 & 19.13 & 7.53 & 2.93 \\
1990 & 470.86 & 12.20 & 80.00 & 2.75 & 23.31 & 10.20 & 3.79 \\
2000 & 459.11 & 11.70 & 78.28 & 2.61 & 23.25 & 10.51 & 3.84 \\
\hline
\end{tabular}

to the total carbon emission production refers a lower bound estimates provided for boreal and tropical peats (Kasischke et al. 2005; Heil, 2007). Emission factors for peat are taken from Christian et al. (2003) and Iinuma et al. (2007).

A monthly seasonality has been added to the original decadal GICC dataset; it is derived from the GFEDv2 seasonality (1997-2006) (van der Werf et al., 2006). The GFEDv2 seasonality was also used to redistribute in space and time total carbon emissions of the following regions in the attempt to improve the carbon emission patterns of the original RETRO data: Contiguous United States, Central America, South America, Northern Hemisphere Africa, Southern Hemisphere Africa, India, Continental Southeast Asia and Australia (for region definition; see Schultz et al., 2008). For the RETRO region Siberia and Mongolia, the redistribution was done using combined information from the GFEDv2 seasonality and the monthly Fire Danger Index (FDI) (described in Schultz et al., 2008). The yearly global total biomass burning carbon emissions of the original datasets remain unchanged from these corrections (deviations less than $1 \%$ from original value), while monthly totals may differ.

Biomass burning emissions are held constant between 1850 and 1900, as no additional information on burned area reconstructions is available (Mouillot et al., 2005). Furthermore, ice-core and charcoal records (McConnell et al., 2007; Marlon et al., 2008) indicate little variations during this time period. The time evolution of biomass burning emissions for the main compounds of interest is shown in Fig. 3. As discussed in Mieville et al. (2010), there is a clear indication of a decrease in global biomass burning emissions after 1900 , a result of the decrease of forest clearing in the mid-latitude 

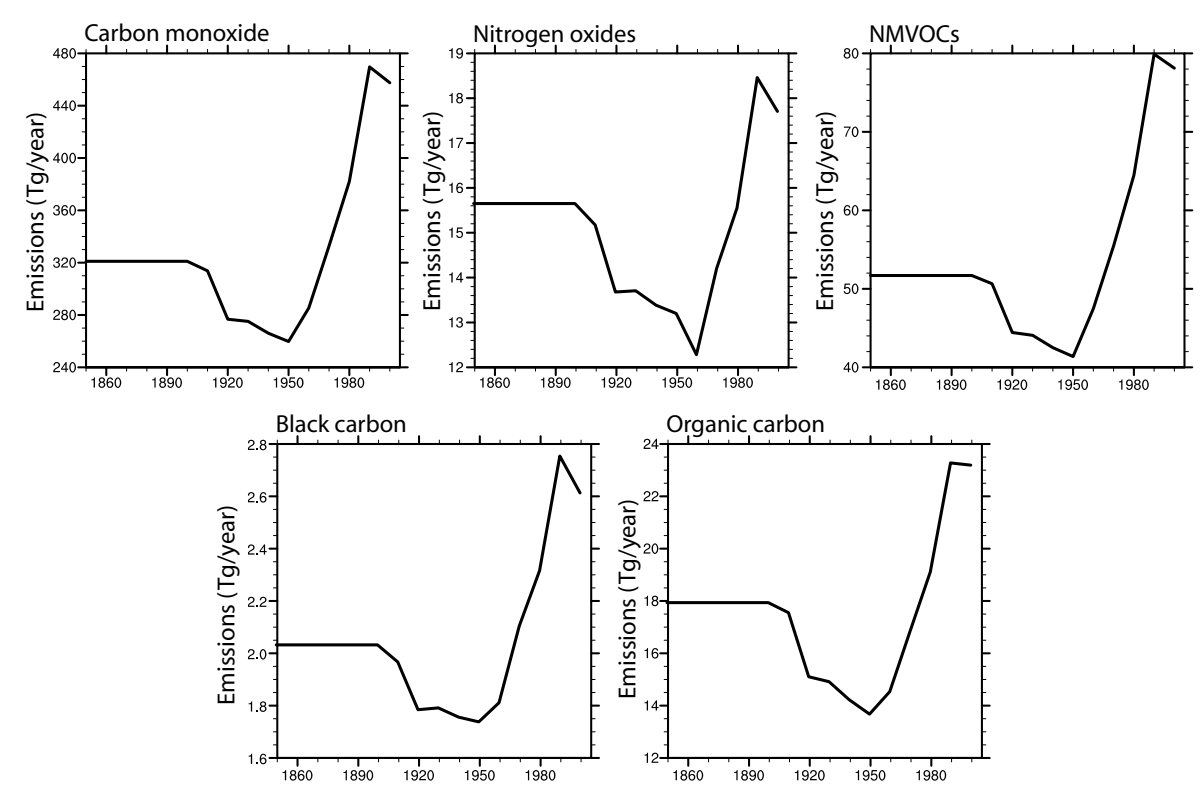

Fig. 3. Time evolution of the total open biomass burning (forest and grassland) emissions for carbon monoxide $(\mathrm{Tg}(\mathrm{CO}) / \mathrm{year}), \mathrm{NO}$ $\left(\mathrm{Tg}\left(\mathrm{NO}_{2}\right) /\right.$ year $)$, NMVOC $(\mathrm{Tg}(\mathrm{NMVOC}) /$ year, black carbon $(\mathrm{Tg}(\mathrm{C}) /$ year $)$ and organic carbon $(\mathrm{Tg}(\mathrm{C}) /$ year $)$.

and boreal regions.

In the distributed emission dataset, no information on vertical distribution is provided. As the separate distribution of grassland and forest fires are provided, users can apply methods similar to Lavoué et al. (2000) (for example) if deemed necessary.

Emissions from fuelwood burning and charcoal production, sometimes also labeled as biomass burning, are accounted for in anthropogenic residential sector emissions (see Sect. 2).

\section{Ship and aircraft emissions}

Total ship emissions, including international shipping, domestic shipping and fishing, but excluding military vessels, are taken from a recent assessment by Eyring et al. (2010) to reflect updated information on the fleet and emission factors. In this latter study, estimates of fuel consumption and $\mathrm{CO}_{2}$ in the year 2000 are based on the International Maritime Organization (IMO) study discussed in Buhaug et al. (2008), while the best-estimate for non- $\mathrm{CO}_{2}$ emission totals is derived as a mean of previous studies (Corbett and Köhler, 2003; Eyring et al., 2005; Endresen et al., 2003, 2007). Ship emissions are distributed over the globe using the International Comprehensive Ocean-Atmosphere Data Set (ICOADS; Wang et al., 2007), which provides changing shipping patterns on a monthly basis. NMVOC emissions from crude oil transport (evaporation during loading, transport, and unloading) from Endresen et al. (2003) were added to the gridded ICOADS ship emission dataset. Consistent with our treatment of other anthropogenic sources, ship emission totals are spread onto the $0.5^{\circ} \times 0.5^{\circ}$ grid boxes without accounting for dispersion, chemical transformation and loss processes on the sub-grid scale. Neglecting the plume processes in global models may lead to an overestimation of ozone formation (Franke et al., 2008; Charlton-Perez et al., 2009).

To extend the non- $\mathrm{CO}_{2}$ ship emissions backward in time, the 2000 emission totals from Eyring et al. (2010) are scaled with the historical $\mathrm{CO}_{2}$ emission time series from Buhaug et al. (2008) back to 1870 . Emissions for 1850 and 1860 are estimated by scaling changes in global ship tonnage as collated by Bond et al. (2007). For the historical geographical ship distribution we use ICOADS data back until 1950. Prior to 1950 s there was much less activity by ships on Pacific routes, with shipping concentrated on the North and South Atlantic oceans, Mediterranean, and Indian/Indonesian trade routes (J. Corbett, personal communication, 2008). To map emissions before 1950, the Pacific trade routes are therefore constrained to go to zero in 1900 , forcing the emissions to be concentrated in the remaining regions. Between 1900 and 1950 a linear interpolation between these patterns is applied to provide decadal gridded ship emissions.

Aircraft emissions of $\mathrm{NO}_{\mathrm{x}}$ and $\mathrm{BC}$ are calculated using the FAST model (Lee et al., 2005) for the European Quantify project (http://www.pa.op.dlr.de/quantify/). Global scheduled and non-scheduled aircraft movements are taken from the AERO2K database (Eyers et al., 2005) for the year 2002. Fuel consumption is calculated using the industry-standard PIANO aircraft performance model (Simos, 2004) for all the main aircraft types including four categories of turbo-props. 


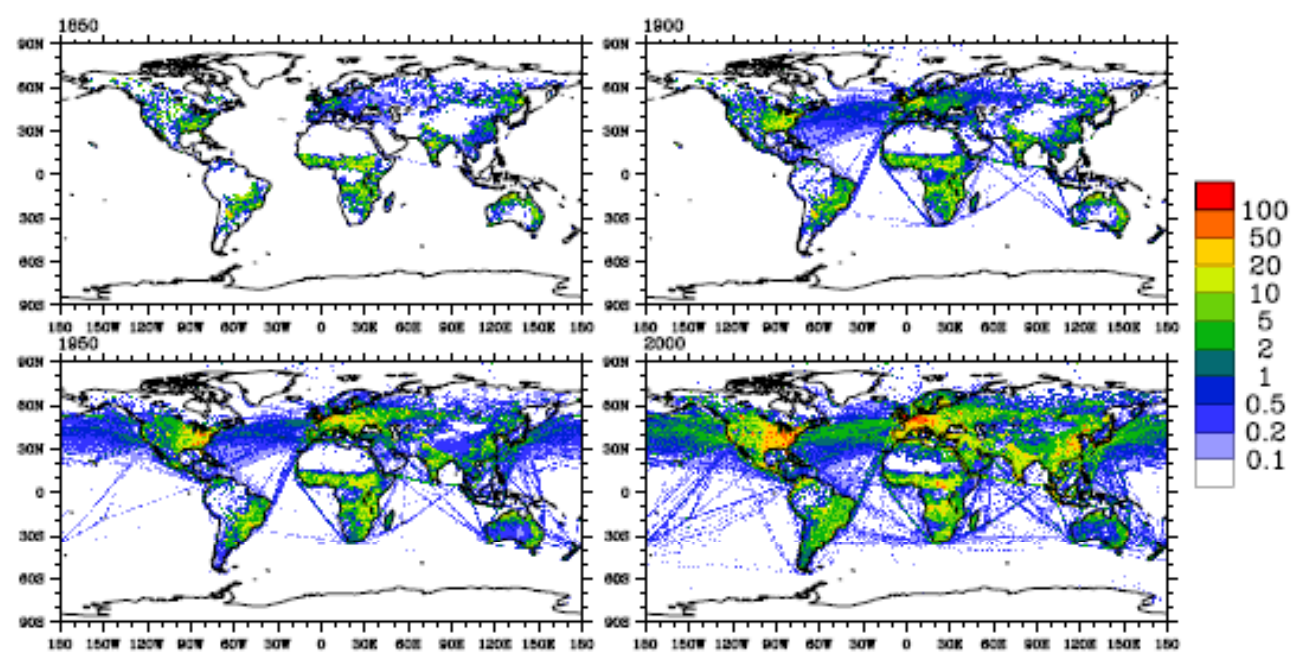

Fig. 4. Total annual emissions (anthropogenic, shipping and biomass burning) of $\mathrm{NO}_{\mathrm{x}}(\mathrm{Tg}(\mathrm{N}) / \mathrm{year}$ ) for 1850 (top left), 1900 (top right), 1950 (bottom left) and 2000 (bottom right).

Fuel consumption is then assigned to the routes using a greatcircle assumption and $\mathrm{NO}_{\mathrm{x}}$ emissions calculated with the Deutsches Zentrum für Luft-und Raumfahrt fuel flow method (Lecht, 1999). BC emissions are calculated using the emission factors developed from Eyers et al. (2005). Monthly distributions were calculated and provided on a 3-D grid with an original resolution of $1^{\circ} \times 1^{\circ}$ latitude/longitude and vertical discretization of flight levels of 2000 feet, which corresponds to the actual (pressure) levels used by air traffic. The vertical distribution of traffic was parameterized from a statistical analysis of EUROCONTROL air traffic data that provided a relationship between mission distance, aircraft type and average cruise altitude (Lee et al., 2005). By convention, aviation "bottom up" inventories underestimate fuel and emissions for a variety of reasons (perfect routing, no stacking, limited data on non-scheduled traffic, military aircraft) when compared with International Energy Agency (IEA) statistics of kerosene sales, so that the three-dimensional inventory presented here is scaled up to the IEA kerosene data to ensure that the global and annual totals are the same.

Historical emissions from aviation are provided on an annual total basis. Data from 1940 to 1995 are taken from Sausen and Schumann (2000) and extended to 2000 using IEA data (the basis of the time series of Sausen and Schumann, 2000). Emissions prior to 1940 are assumed to exponentially decay such that the emissions by 1910 are zero. This is clearly of limited importance since emissions in 1940 and before are believed to be quite small.

\section{Application}

We have described above (see Figs. 1-4) how changes in emissions at the global scale have been very significant between 1850 and 2000. It is however important to remem- ber that these changes have very different regional characteristics (Fig. 4 for the specific case of $\mathrm{NO}_{\mathrm{x}}$ emissions) and only global three-dimensional chemistry-climate models can fully capture the implications. Therefore, in this section, we discuss the application of the emissions described above to the simulation of tropospheric composition changes between 1850 and present by two chemistry-climate models: CAM-Chem and G-PUCCINI. Of those two models only CAM-chem includes an interactive representation of aerosols (i.e. G-PUCCINI reads in previously generated aerosol distributions). Analysis of the modeled results against available observations provides an initial understanding of successes and limitations of the emissions described in this paper; note that the results presented below include natural emissions not discussed in this paper.

\subsection{Model description and simulation setup}

\subsubsection{CAM-Chem}

We use the Community Atmosphere Model version 3.5 (Gent et al., 2009) modified to include interactive chemistry (i.e. with feedback to the radiation calculation in the atmosphere) to calculate distributions of gases and aerosols. The model configuration used in this study includes a horizontal resolution of $1.9^{\circ}$ (latitude) by $2.5^{\circ}$ (longitude) and 26 hybrid levels, from the surface to $\approx 40 \mathrm{~km}$ with a timestep of $30 \mathrm{~min}$; the transient simulation was performed continuously between 1850 and 2009. In order to simulate the evolution of the atmospheric composition over the recent past, the chemical mechanism used in this study is formulated to provide an accurate representation of both tropospheric and stratospheric chemistry (Lamarque et al., 2008). Specifically, to successfully simulate the chemistry above $100 \mathrm{hPa}$, we include a representation of stratospheric chemistry (including 
polar ozone loss associated with stratospheric clouds) from version 3 of MOZART (MOZART-3; Kinnison et al., 2007). The tropospheric chemistry mechanism has a limited representation of non-methane hydrocarbon chemistry in addition to standard methane chemistry, extended from Houweling et al. (1998) with the inclusion of isoprene and terpene oxidation and updated to JPL-2006 (Sander et al., 2006). This model has a representation of aerosols based on the work by Tie et al. $(2001,2005)$, i.e. sulfate aerosol is formed by the oxidation of $\mathrm{SO}_{2}$ in the gas phase (by reaction with the hydroxyl radical) and in the aqueous phase (by reaction with ozone and hydrogen peroxide). Furthermore, the model includes a representation of ammonium nitrate that is dependent on the amount of sulfate present in the air mass following the parameterization of gas/aerosol partitioning by Metzger et al. (2002). Because only the bulk mass is calculated, a lognormal distribution is assumed for all aerosols using different mean radius and geometric standard deviation (Liao et al., 2003). The conversion of carbonaceous aerosols (organic and black) from hydrophobic to hydrophilic is assumed to occur within a fixed 1.6 days. Natural aerosols (desert dust and sea salt) are implemented following Mahowald et al. (2006a, b), and the sources of these aerosols are derived based on the model calculated wind speed and surface conditions.

At the lower boundary, the time-varying (monthly values) zonal-averaged distributions of $\mathrm{CO}_{2}, \mathrm{CH}_{4}, \mathrm{H}_{2}$ and all the halocarbons (CFC-11, CFC-12, CFC-113, HCFC-22, H1211, $\mathrm{H}-1301, \mathrm{CCl}_{4}, \mathrm{CH}_{3} \mathrm{CCl}_{3}, \mathrm{CH}_{3} \mathrm{Cl}$ and $\mathrm{CH}_{3} \mathrm{Br}$ ) are specified following the datasets used in Garcia et al. (2007). In addition, the monthly-mean time-varying sea-surface temperatures (SSTs) and sea-ice distributions are taken from a 20th century CCSM-3 simulation (Meehl et al., 2008); as this simulation only extended from 1870 to present, the seasurface temperature and ice extent between 1850 and 1870 are assumed to be the same as 1870 .

\subsubsection{G-PUCCINI}

Simulations are performed with the Goddard Institute for Space Studies (GISS) model for Physical Understanding of Composition-Climate INteractions and Impacts (GPUCCINI) (Shindell et al., 2006b). Its behavior in the GISS AR4 version of the climate model has been documented and extensively compared with observations (e.g. Dentener et al., 2006; Shindell et al., 2006a, b; Stevenson et al., 2006). Tropospheric chemistry includes basic $\mathrm{NO}_{\mathrm{x}}-\mathrm{HO}_{\mathrm{x}}-\mathrm{O}_{\mathrm{x}}-\mathrm{CO}-\mathrm{CH}_{4}$ chemistry as well as peroxyacetylnitrates and the hydrocarbons isoprene, alkyl nitrates, aldehydes, alkenes, and paraffins. The lumped hydrocarbon family scheme was derived from the Carbon Bond Mechanism-4 (CBM-4) and from the more extensive Regional Atmospheric Chemistry Model (RACM), following Houweling et al. (1998). To represent stratospheric chemistry, the model includes chlorine- and bromine-containing compounds, and $\mathrm{CFC}$ and $\mathrm{N}_{2} \mathrm{O}$ source gases. The chemistry used here is quite similar to that documented previously, with a few additions: acetone has been added to the hydrocarbons included in the model following Houweling et al. (1998), polar stratospheric cloud formation is now dependent upon the abundance of nitric acid, water vapor and temperature (Hanson and Mauersberger, 1988), and a reaction pathway for $\mathrm{HO}_{2}+\mathrm{NO}$ to yield $\mathrm{HNO}_{3}$ has been added (Butkovskaya et al., 2007). Chemical calculations are performed seamlessly throughout the troposphere and stratosphere. The full scheme includes 156 chemical reactions among 50 species with a time step of $20 \mathrm{~min}$. Photolysis rates are calculated using the Fast-J2 scheme (Bian and Prather, 2002), whereas other chemical reaction rate coefficients are from JPL-2000 (Sander et al., 2000).

The chemistry model is fully embedded in the GISS modelE climate model (Schmidt et al., 2006). For the simulations described here, we have used the development version of the model near its "frozen" state for AR5 simulations. This version of the model has an equilibrium climate sensitivity of $3.7^{\circ} \mathrm{C}$ for a doubling of $\mathrm{CO}_{2}$. The model was run at $2^{\circ}$ latitude by $2.5^{\circ}$ longitude Cartesian horizontal resolution, with increased effective resolution for tracers by carrying higher order moments at each grid box. This configuration had 40 vertical hybrid sigma layers from the surface to $0.01 \mathrm{hPa}(\approx 80 \mathrm{~km})$. Tracer transport uses a non-diffusive quadratic upstream scheme (Prather, 1986). Time-slice simulations were performed every 20 years during the 1850-1930 time period, and every 10 years from 1930-2000. Values were then interpolated to give decadal means. Simulations were carried out for 8 years, with the average of the last five used for analysis. The GCM was driven by observed decadal mean sea-surface temperatures and sea-ice distribution (Rayner et al., 2003) and prescribed abundances of longlived greenhouse gases.

\subsection{Evaluation of model results}

In this section, we focus our evaluation on long-term trends in surface and mid-troposphere ozone (both models), surface concentration of carbon monoxide (both models) and aerosol optical depth and aerosol deposition (CAM-chem only); indeed, the main purpose for the emission dataset described above is to be used for studies of long-term changes in tropospheric composition of relevance to climate radiative forcing. Emissions and their applications beyond year 2000 will be discussed elsewhere.

\subsubsection{Surface ozone}

Observations of surface ozone over the last decades indicate a significant rise in the Northern Hemisphere (Parrish et al., 2004; Oltmans et al., 2006; Derwent et al., 2007). We focus here on stations with at least 20 years of observations (Table 10), providing timeseries for comparison with model results. Model ozone fields are interpolated to the 
Table 10. List of stations.

\begin{tabular}{lcccc}
\hline Station name & Latitude & Longitude & Altitude $(\mathrm{m})$ & Period \\
\hline Arkona/Zingst & $54.4 \mathrm{~N}$ & $13.26 \mathrm{E}$ & 42 & Sep 1956-Jun 2004 \\
Barrow & $71.32 \mathrm{~N}$ & $156.6 \mathrm{~W}$ & 11 & Mar 1973-Dec 2005 \\
Cape Matatula & $14.24 \mathrm{~S}$ & $170.57 \mathrm{~W}$ & 42 & Sep 1975-Dec 2004 \\
Hohenpeissenberg & $47.89 \mathrm{~N}$ & $11.02 \mathrm{E}$ & 985 & Jan 1995-Dec 2007 \\
Mace Head & $53.33 \mathrm{~N}$ & $9.9 \mathrm{~W}$ & 25 & Nov 1987-Sep 2006 \\
Maunao Loa & $16.54 \mathrm{~N}$ & $155.58 \mathrm{~W}$ & 3397 & Sep 1973-Dec 2004 \\
South Pole & $89.90 \mathrm{~S}$ & $24.8 \mathrm{~W}$ & 2810 & Jan 1975-Dec 2004 \\
US Pacific Coast & N/A & N/A & N/A & Mar 1988-Feb 2007 \\
Zugspitze & $47.42 \mathrm{~N}$ & $10.98 \mathrm{E}$ & 2960 & Jan 1995-Dec 2002 \\
\hline
\end{tabular}

Table 11. Linear trend in surface ozone (ppbv/year)

\begin{tabular}{lccc}
\hline & Observations & CAM-chem & G-PUCCINI \\
\hline Hohenpeissenberg & 0.32 & 0.18 & 0.22 \\
Zugspitze & 0.40 & 0.24 & 0.23 \\
Mace Head & 0.18 & 0.17 & 0.17 \\
Arkona & 0.36 & 0.14 & 0.16 \\
US Pacific coast & 0.33 & 0.21 & 0.19 \\
Barrow & 0.04 & 0.10 & 0.06 \\
Mauna Loa & 0.15 & 0.28 & 0.17 \\
Samoa & -0.03 & 0.05 & 0.00 \\
South Pole & -0.05 & 0.03 & -0.20 \\
\hline
\end{tabular}

location of the observations, including altitude. Because the observations over the United States Pacific coast (Table 10) are filtered to only provide background conditions (Parrish et al., 2004), the analysis of the model results is performed using surface ozone from approximately $200 \mathrm{~km}$ west of the actual station location. In addition, in the case of Mace Head, background (Derwent et al., 2007) and unfiltered surface ozone (from http://tarantula.nilu.no/projects/ ccc/emepdata.html) observations are available; we use the unfiltered data, as they are more representative of the modeled field.

Over the European sites (Fig. 5, top), both models (with small inter-model difference) provide a good representation of present-day observed surface ozone, except at Arkona where G-PUCCINI tends to overpredict the observed concentration by approximately 8 ppbv.

Between 1990 and 2000, the model results and the observations agree quite well with each other, indicating that the recent trends in emissions are probably well captured for the this region. Prior to 1990 , the observations tend to decrease substantially faster (approximately twice as fast) than the models simulate (see Table 11 for a comparison of observed and modeled trends). In particular, observations in Arkona during the mid-1980s show very low values (less than $20 \mathrm{ppbv}$ ). Without any indication of problem with the
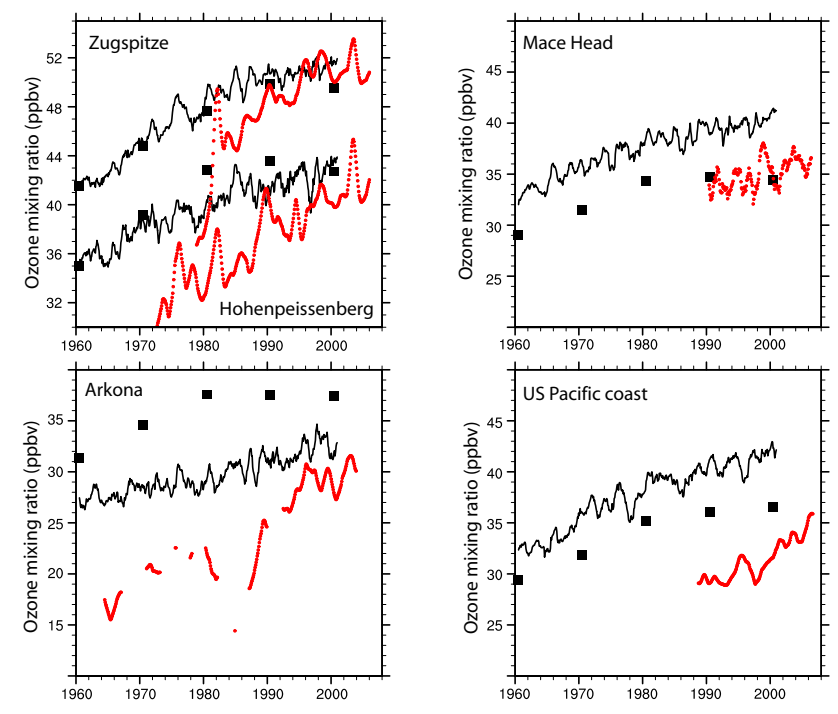

Fig. 5. Time evolution (1960-2009) of surface ozone (12-month running mean) at a variety of sites. Observations are in red, CAMchem results are in black (solid line) and G-PUCCINI results are in black (solid squares).

observations, it is clear that neither model is able to represent such distribution. A possible explanation is that highly localized emission patterns not captured by our emission dataset could have led to those very low ozone concentrations. The overall agreement between the two models in the simulated long-term tendencies (Fig. 5) indicate that the smaller-thanobserved modeled trend prior to 1990 is most likely due to a limitation of our emission datasets. The overestimation of ozone in the Northern Hemisphere is however another indication that it is unlikely that the $\mathrm{CO}$ emissions (an important ozone precursor) in 1970 and 1980 from the US (one of the largest contributors at the time) could have been as large as indicated by the EPA-2006 estimates. Similar conclusions can be reached for the $\mathrm{NO}_{\mathrm{x}}$ emissions defined in this study. 

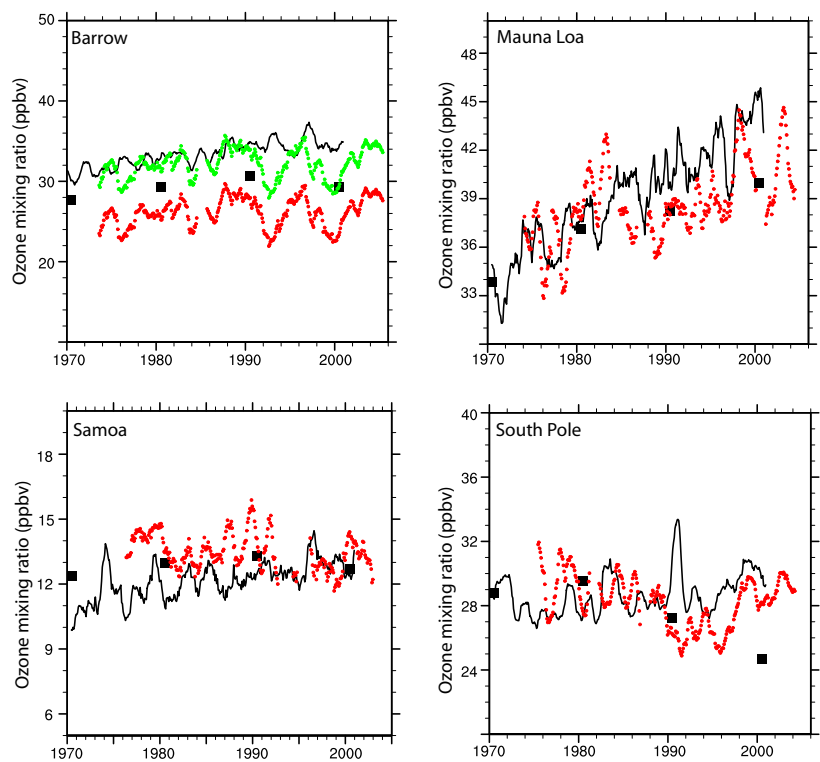

Fig. 6. Time evolution (1970-2009) of surface ozone (12-month running mean) at a variety of sites. Observations are in red, CAMchem results are in black (solid line) and G-PUCCINI results are in black (solid squares). A constant value of $6 \mathrm{ppbv}$ was added to the Barrow observations to take into account model deficiencies; this is shown as green dots.

Over the US Pacific Coast, the models are again quite similar to one another, but neither matches the rapid increase in surface ozone seen in observations in recent years (Parrish et al., 2004).

However, additional long-term records of surface ozone (Barrow, Alaska; Mauna Loa, Hawaii; Cape Matatula, American Samoa; South Pole, Antarctica, Fig. 6) show a different picture, in which changes in ozone in the 1980s are not increasing as rapidly, if at all. In particular, the record at Samoa actually indicates a long-term decrease in ozone, contrary to the findings of Lelieved et al. (2004). In all those places, both models perform quite well in their capture of the longterm trends (note that, for visualization purposes, a constant bias of $6 \mathrm{ppbv}$ was added to the observed record at Barrow to match the simulated levels; this is likely due to the specific environment at Barrow, at the edge of the Arctic Ocean, which is difficult to capture with a coarse-grid global model). At Samoa, climate trends may have played a substantial role in the apparent decrease between $\sim 1990$ and $\sim 2000$ in the observations, as the models have rather different trends despite the same emissions data. The use of observed SSTs in the G-PUCCINI simulations may have allowed it to capture local climate changes that could have contributed to the recent ozone decline seen in that remote Western Pacific location. At the South Pole, there is indication of the impact of stratospheric ozone depletion, bringing minimal levels during the mid-1990s, followed by a slight recovery and leveling-off since 2000 (Chipperfield et al., 2007). CAM- chem is better able to capture this trend (Table 11), while GPUCCINI tends to underestimate ozone in 2000, apparently due to an overestimate of downward transport of air having experienced Antarctic stratospheric ozone depletion (unlike the surface, stratospheric ozone did not recover to the values seen in the 1970s and early 1980s by 2000; Chipperfield et al., 2007).

Neither model is capable of reproducing the Montsouris record (Volz and Kley, 1988), similar to the results of Lamarque et al. (2005) and references therein. On the other hand, in terms of tropospheric ozone change (surface to $200 \mathrm{hPa}$ ), we find a very good agreement with the results of Gauss et al. (2006) with an increase of approximately 9 DU between 1850 and 2000.

\subsubsection{Surface carbon monoxide}

Comparison (Fig. 7) of modeled and observed (averaged 1990s conditions) surface carbon monoxide at Mace Head (a useful comparison since this station also provides surface ozone, Fig. 5) indicates a negative bias (approximately $20 \mathrm{ppbv}$ ) and a somewhat reduced seasonal cycle, with a larger negative bias during winter. These features are present in both simulations and are found at most of the Northern Hemisphere stations (not shown); agreement during summer conditions seems to always be slightly better than in the winter. Biases in the Southern Hemisphere are much smaller (especially for CAM-chem, not shown). The overall Northern Hemisphere negative bias in both model simulations points towards an underestimation of the carbon monoxide (and possibly NMVOCs) in our dataset; however, comparison with other published estimates (Table 5) does not indicate a clear negative bias in either anthropogenic or biomass burning emissions of carbon monoxide. Owing to the long lifetime of carbon monoxide during winter (up to a few months; Edwards et al., 2005), it is possible that biomass burning emissions in the latter part of the year over Russia are not well enough characterized to provide the wintertime maximum (Edwards et al., 2005). But, further analysis (beyond the scope of this paper) is required to fully understand the reason for this low bias.

The long-term change (between 1990 and present, Fig. 8) in carbon monoxide at Mace Head (using unfiltered observations, see http://tarantula.nilu.no/projects/ccc/emepdata. html) shows that the models capture the recent change relatively well; it is clear however that this analysis suffers from the lack of long-term ( $>10$ years) records. Interestingly, the simulated change in surface CO at Mace Head between 1960 and 1990 is quite different between the two models, much more so than the ozone change over the same period.

The lifetimes of $\mathrm{CO}$ and $\mathrm{CH}_{4}$ can be used as global measures of the $\mathrm{OH}$ content of the atmosphere. For the 2000 conditions, the methane chemical lifetime (i.e. not including the small deposition flux as the simulations were performed with specified bottom layer methane concentration) is 8.9 years 


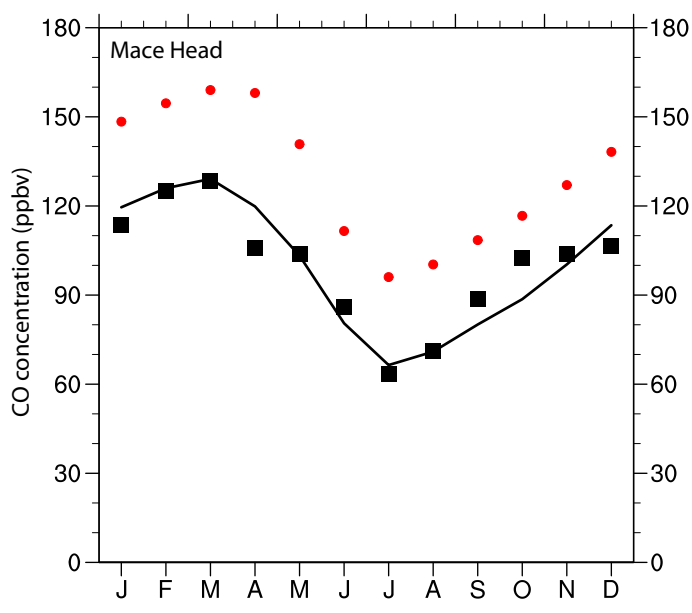

Fig. 7. Seasonal cycle of carbon monoxide (ppbv) at Mace Head for the 1990s. Observations (averaged 1991-1999) are in red, CAMchem results are in black (solid line) and G-PUCCINI results are in black (solid squares).

for CAM-chem and 8.6 years for G-PUCCINI, in excellent agreement with the IPCC AR-4 estimates of $8.7 \pm 1.3$ years (Denman et al., 2007). For the same period, the CO lifetime is 1.7 months for CAM-chem, in good agreement with Horowitz et al. (2003). There is therefore no indication that a significant bias in $\mathrm{OH}$ in our model simulations could explain the low bias in $\mathrm{CO}$.

\subsubsection{Mid- and upper-tropospheric ozone}

A compilation of mid-tropospheric ozone observations from a variety of platforms (Cooper et al., 2010) indicates that Western United North America $\left(25^{\circ}-55^{\circ} \mathrm{N}, 130^{\circ}-90^{\circ} \mathrm{W}\right.$, $3-8 \mathrm{~km})$ has experienced a recent (1995-2008) increase in ozone concentration (Fig. 9), most likely associated with Asian emissions. The model results indicate again that they are performing very well in estimating the present-day (2000) ozone concentration. Evidently, they are not able to reproduce inter-annual variability but our 5- to 10 -yr averages are close to the observed values. Similarly to Fig. 5, the two models exhibit a consistent long-term evolution. Ths observational dataset provides a much lower 1980s ozone concentration than the models indicate, similar to the surface ozone analysis above.

\subsubsection{Aerosol optical depth, burden and lifetime}

A useful measure of the radiative impact of aerosols can be evaluated through the calculation of the aerosol optical depth (Schulz et al., 2006). We display in Fig. 10 the CAM-chem simulated annual average total aerosol optical depth (AOD) at $550 \mathrm{~nm}$ for 1850 and 2000 . The occurrence of widespread pollution over the Northern Hemisphere is clearly identifiable. In terms of the global average, the 2000 AOD sim-

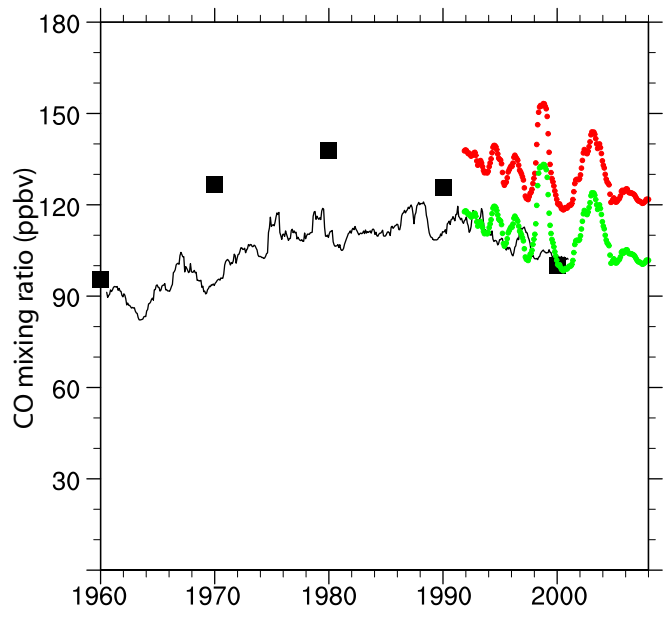

Fig. 8. Time evolution (1960-2009) of surface CO (12-month running mean) at Mace Head. Observations are in red, CAM-chem results are in black (solid line) and GPUCCINI results are in black (solid squares). A constant value of $25 \mathrm{ppbv}$ was subtracted from the observations to take into account model deficiencies; this is shown as green dots.

ulated value is 0.12 , which represents an increase of 0.033 over the 1850 conditions (0.087). This anthropogenic increase is very much in agreement with the average AeroCom results (Schulz et al., 2006). We also compare our annual average aerosol optical depths to AERONET sun photometer site data at 173 sites globally (Holben, et al., 1998). Sun photometry data represents some of the highest quality data for assessing total aerosol optical depth. We include all stations where monthly averages at $500 \mathrm{~nm}$ were available for all 12 months. The model is able to capture much of the variability, but underestimates the aerosols optical depth at high observed values (Fig. 11). The correlation coefficient between modeled values and observations is 0.67 . In terms of dust and sea-salt aerosols, comparison with surface observations (using iron deposition as a proxy, see Fig. 12) indicates a reasonable representation of present-day conditions.

An additional important evaluation for aerosol is their global burden and lifetime. Results for the 2000 conditions are summarized in Table 6. Compared to the AeroCom results (Schulz et al., 2006), the lifetime of carbonaceous aerosols is approximately 2 days shorter (from approximately 7.5 days to 5.5 days), leading to a smaller burden. On the other hand, sulfate lifetime is almost exactly the same, as is the anthropogenic contribution (i.e. the difference between 2000 and 1850 burdens).

\subsubsection{Aerosol ice-core deposition}

Ice core measurement of aerosol and gas content can provide information on long-term changes in deposition and concentration. In particular, Greenland ice cores have been recently used to study the importance of black carbon in the 


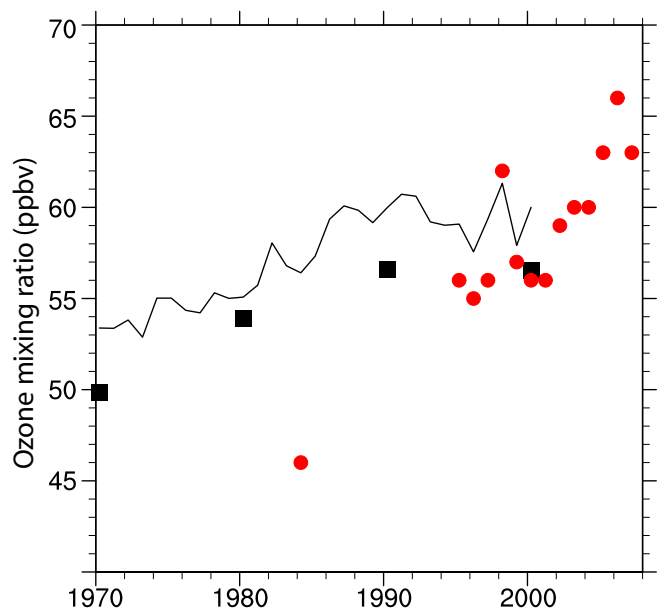

Fig. 9. Time evolution (1970-2009) of mid-troposphere ozone (springtime mean) from Cooper et al. (2010). Observations are in red, CAM-chem results are in black (solid line) and G-PUCCINI results are in black (solid squares).
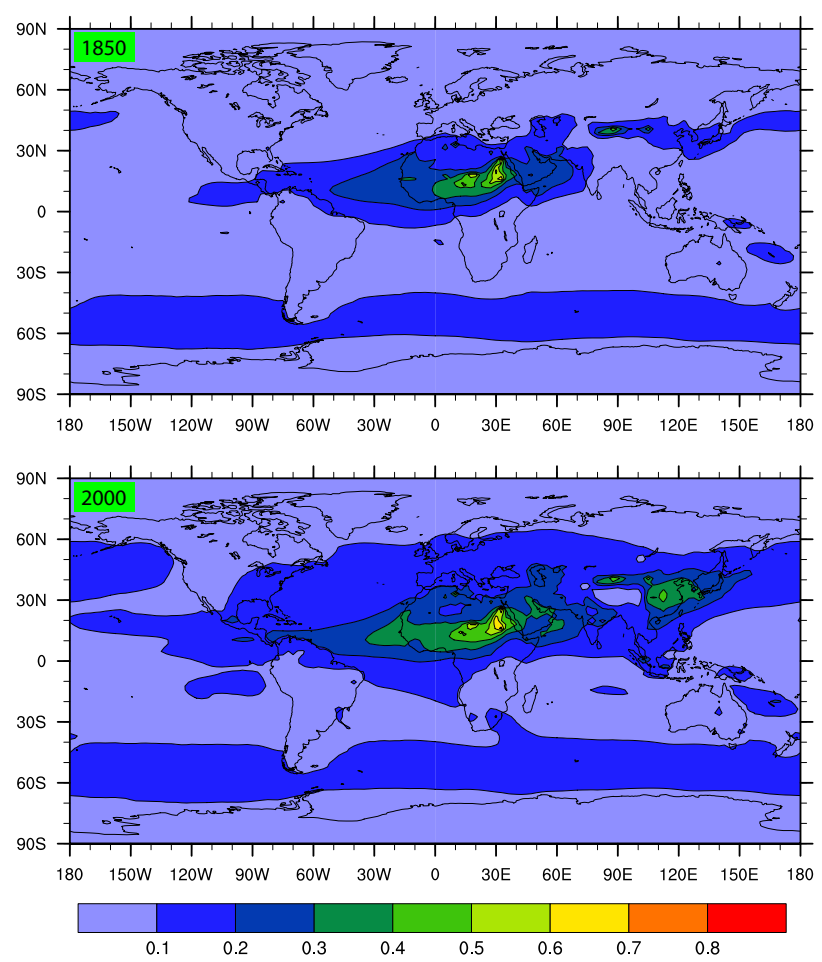

Fig. 10. Total (natural and anthropogenic) CAM-chem simulated aerosol optical depth at $550 \mathrm{~nm}$ (decadal average) for 1850 and 2000.

Arctic (McConnell et al., 2007). The model results (wet and dry deposition of sulfate and black carbon) are interpolated to the model grid point nearest to the D4 ice core site $\left(71.4^{\circ} \mathrm{N}, 44^{\circ} \mathrm{W}\right)$ with the closest model topography altitude to D4 (approx. $100 \mathrm{~km}$ north of the actual D4 loca-

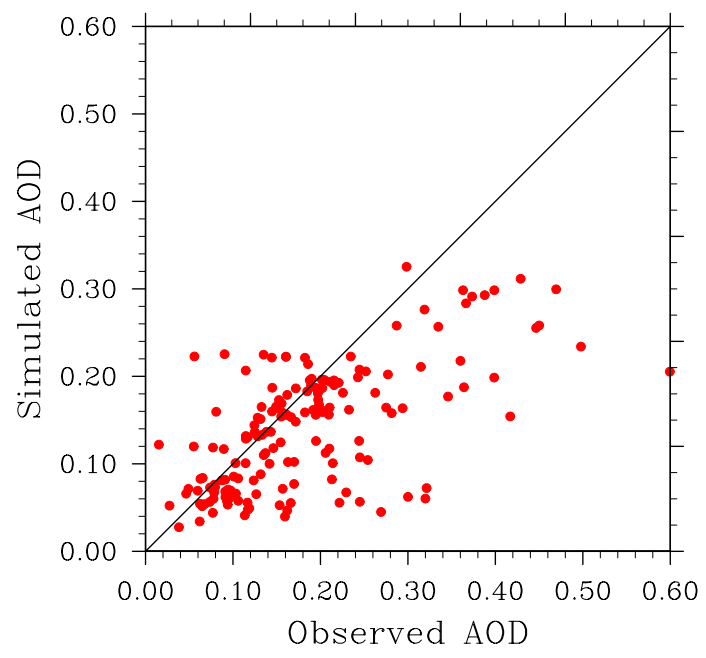

Fig. 11. Comparison between observed and modeled (present-day) annually aerosol optical depth at $500 \mathrm{~nm}$. The observed values are based on annually averaged AERONET optical depths (Holben et al., 1998).

tion); indeed, precipitation patterns (and therefore deposition) exhibit a strongly decreasing latitudinal gradient across the Greenland ice sheet. There is a remarkable agreement (Fig. 13, top) between the observations and the simulated deposition. In terms of sulfate, the maximum deposition rate ( $40 \mathrm{mg} / \mathrm{m}^{2} /$ year in the observations) occurs in 1980 , when the global emissions (but especially over the United States and Russia) peaked (Fig. 2). There is also indication of a local maximum sulfate deposition at the beginning of the 20th century in both the observations and the model field.

Similarly (Fig. 13, bottom), black carbon (hydrophilic only) deposition at D4 has peaked in the early part of the 20th century. We find that, using the same sampling procedure as for sulfate, the model captures that feature quite well (albeit not as strongly as the observations suggest), along with the overall changes over the simulated period. This is again indicative of adequate regional emission changes in North America as Greenland deposition is most strongly influenced by emissions in that region (Shindell et al., 2008), in this case related to changes (in both anthropogenic emissions increasing, see Fig. 2) and biomass burning (decreasing, see Fig. 3).

\section{Discussion and conclusions}

We have presented in this paper a dataset of historical anthropogenic (defined here as originating from industrial, domestic and agriculture activity sectors) and biomass burning emissions of reactive gases and aerosols covering 1850 2000. This dataset builds upon and complements previous inventories. In particular, our dataset represents a combination of existing regional and global inventories (Table 4), 


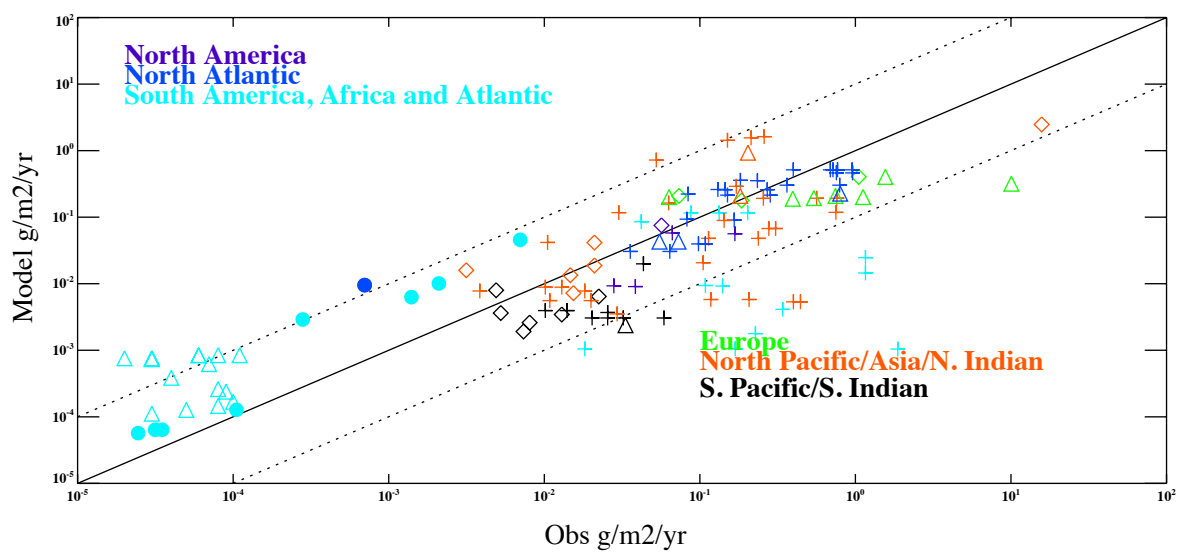

Fig. 12. Comparison between observed and modeled (present-day) iron concentration at a variety of sites $\left(\mathrm{g} / \mathrm{m}^{2} / \mathrm{year}\right)$. The compiled observations are available from Mahowald, et al. (2009).
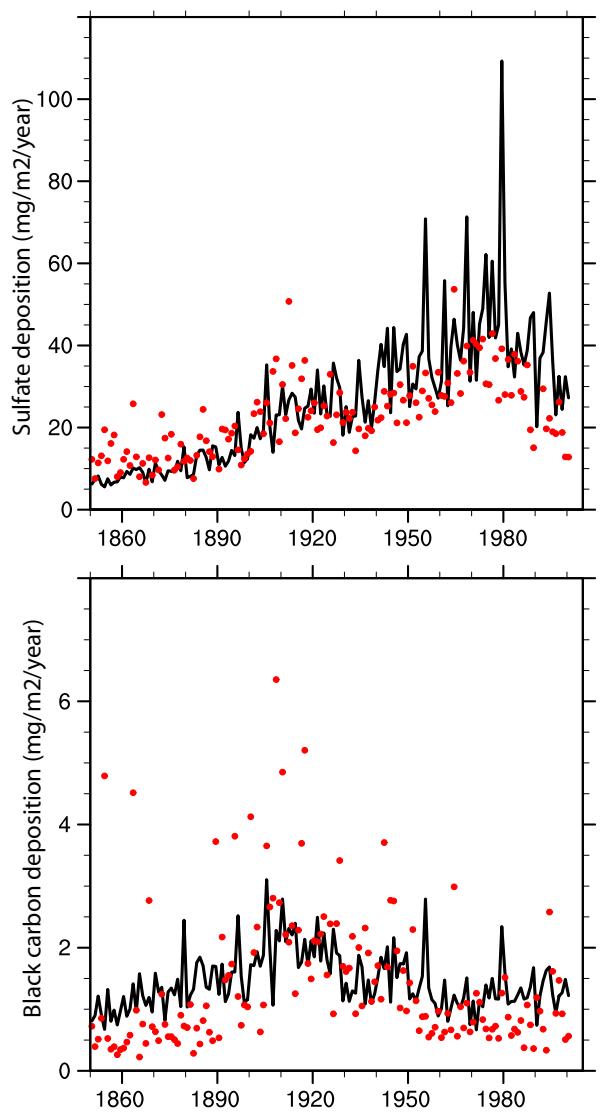

Fig. 13. Deposition (annual average) over Greenland (D4 site) of sulfate and black carbon. Ice-core observations are in red and CAM-chem results are in black.

and the combination of information was performed on a regional (40 regions) and sectoral (12 sectors) representation (Tables 2 and 3). Of course, the use of a variety of inventories precludes full consistency between car-
Table 12. Global burden and lifetime for anthropogenicallyperturbed aerosols in 1850 and 2000 for the CAM-chem simulation.

\begin{tabular}{|c|c|c|c|}
\hline & & 1850 & 2000 \\
\hline \multicolumn{4}{|l|}{ Sulfate } \\
\hline & Burden $\left(\mathrm{mg}\left(\mathrm{SO}_{4}\right) / \mathrm{m}^{2}\right)$ & 1.55 & 3.65 \\
\hline & Lifetime (days) & 3.4 & 3.6 \\
\hline \multicolumn{4}{|l|}{ Black carbon } \\
\hline & Burden $\left(\mathrm{mg}(\mathrm{C}) / \mathrm{m}^{2}\right)$ & 0.09 & 0.24 \\
\hline & Lifetime (days) & 5.6 & 5.8 \\
\hline \multicolumn{4}{|l|}{ Organic carbon } \\
\hline & Burden $\left(\mathrm{mg}(\mathrm{C}) / \mathrm{m}^{2}\right)$ & 0.64 & 1.04 \\
\hline & Lifetime (days) & 5.2 & 5.4 \\
\hline
\end{tabular}

bon dioxide, reactive gases and aerosol emissions for anthropogenic, biomass burning, land-use and natural emissions. It is unclear how important this lack of full consistency is, but it will be important to focus on this issue in future similar emission datasets. All data are publicly available at http://www.iiasa.ac.at/web-apps/tnt/RcpDb and $\mathrm{ftp} / / / \mathrm{ftp}$-ipcc.fz-juelich.de/pub/emissions/.

The primary purpose of this inventory is to provide emissions for chemistry-climate simulations (with the Climate Model Intercomparison Program \#5 in support of the IPCC AR5 as the overall focus) for the study of long-term changes in atmospheric composition. In particular, the emissions for year 2000 serve as an anchor point for historical emissions (as discussed in this paper) and future emissions (as will be discussed in separate publications). This ensures continuity in emission datasets throughout the period of interest (1850-2100). Because of its focus on long-term 
changes, this dataset provides emissions every 10 years and does not attempt to reproduce interannual variability, which can be significant, particularly for biomass burning emissions.

Based on the recent studies by Bond et al. (2004, 2007) and Smith et al. (2010) uncertainties in regional emissions can be expected to be as large as a factor of 2 (or even larger). The comparison of our year 2000 emissions with published estimates does not indicate significant biases (Table 5). However, large differences with the EPA-2006 estimates of the US. CO emissions for 1970 and 1980 are found (Table 6), with the possible explanation that those EPA estimates are themselves strongly overestimated (Parrish, 2006). Other species display a smaller spread amongst estimates and our dataset tends to fall within the range of published estimates.

Using two chemistry-climate models, we have performed 1850-2000 simulations (transient or time-slice experiments) in order to provide a first-order evaluation of the emissions. The focus of this evaluation is on long-term changes of tropospheric species relevant to climate forcing. In particular, we find that the model simulations for the 1990-2000 conditions represent quite well the observed surface and midtroposphere ozone distributions. There is however indication that the modeled long-term increase since the early 1980s is not as strong and rapid as recent publications indicate (Parrish et al., 2004; Cooper et al., 2010), at least in the Northern mid-latitudes. Indeed, comparison with other long-term ozone records (Barrow, Mauna Loa, Samoa and South Pole) shows good agreement for the available period 1970-2000; there is therefore clearly a need for understanding ozone changes at the regional scale. We found that, in our simulations, carbon monoxide is biased low in both models; the reason for this bias (present in many sites over the Northern Hemisphere but not so much in the Southern Hemisphere) is not clear at this point.

Ice-core deposition of sulfate and black carbon over Greenland is well simulated (albeit only the CAM-chem model has simulated aerosols) in both amplitude and longterm trend. In particular, the black carbon maximum at the turn of the 20th century is a combination of increasing anthropogenic and decreasing biomass burning emissions. In addition, global measures of aerosol content are inline with the AeroCom estimates (Schulz et al., 2006) for present-day burden and lifetime, especially for sulfate. Finally, aerosol optical depth comparison with AERONET observations indicates a reasonably good simulation of present-day conditions.

The observations of long-term changes in atmospheric composition clearly indicate large regional variations. As discussed in our paper, modeling these changes is a difficult challenge that combines the role of changing emissions and changing climate.

The dataset and simulations discussed here have in particular shown the continuing underestimate of the long-term trends in surface and mid-troposphere ozone, especially for the continuous surface records from as early as the 1970s for several stations. Similar to the Montsouris early 1900s observations (Volz and Kley, 1988), the simulation of the full amplitude of those observed trends remains problematic, possibly highlighting limits in our present understanding of tropospheric ozone.

Acknowledgements. The authors would like to thank the ACCENT European Network, which provided funding for meetings to develop the emissions dataset. Suvi Monni, Lorenzo Orlandini and Valerio Pagliari are acknowledged for providing support in the gridding of emissions and making available official reported data from EMEP and UNFCCC inventories. O. Buhaug and J. Corbett provided helpful comments on ship emissions. Z. K. would like to acknowledge the support received from the European Integrated project on Aerosol Cloud Climate and Air Quality Interactions (EUCAARI), a project within EU's Sixth Framework Program. A.H. acknowledges funding from the European Union's CITYZEN project. Surface data was obtained from the World Data Centre for Greenhouse gases, maintained by the Japan Meteorological Agency in cooperation with the World Meteorological Organization. We would like to thank D. Parrish and H.-E. Scheel for providing access to their ozone datasets. AERONET data was kindly made available by the AERONET investigators and used for this study. The National Center for Atmospheric Research is operated by the University Corporation for Atmospheric Research under sponsorship of the National Science Foundation. Any opinions, findings and conclusions or recommendations expressed in the publication are those of the author(s) and do not necessarily reflect the views of the National Science Foundation.

Edited by: R. Harley

\section{References}

Andreae, M. O. and Merlet, P.: Emission of trace gases and aerosols from biomass burning, Global Biogeochem. Cy., 15, 955-966, 2001.

Andres, R. J., Fielding, D. J., Marland, G., Boden, T. A., Kumar, N.: Carbon dioxide emissions from fossil-fuel use, 1751-1950, Tellus, 51, 759-765, 1999.

Beusen, A. H. W., Bouwman, A. F., Heuberger, P. S. C., Van Drecht, G., and Van Der Hoek, K. W.: Bottom-up uncertainty estimates of global ammonia emissions from global agricultural production systems, Atmos. Environ., 42(24), 6067-6077, 2008.

Bian, H. and Prather, M.: Fast-j2: Accurate simulations of photolysis in global climate models, J. Atmos. Chem., 41, 281-296, 2002.

Bond, T. C., Streets, D. G., Yarber, K. F., Nelson, S. M., Woo, J.-H., Klimont, Z.: A Technology-Based Global Inventory of Black and Organic Carbon Emissions from Combustion, J Geophys. Res., 109, D14203, doi:10.1029/2003JD003697, 2004.

Bond, T. C., Bhardwaj, E., Dong, R., Jogani, R., Jung, S., Roden, C., Streets, D. G., and Trautmann, N. M.: Historical emissions of black and organic carbon aerosol from energy-related combustion, 1850-2000, Global Biogeochem. Cy., 21, GB2018, doi:10.1029/2006GB002840, 2007.

Buhaug, Ø., Corbett, J. J., Endresen, Ø., Eyring, V., Faber, J., Hanayama, S., Lee, D. S., Lindstad, H., Mjelde, A., Pålsson, 
C., Wanquing, W., Winebrake, J. J., and Yoshida, K.: Updated Study on Greenhouse Gas Emissions from Ships: Phase I Report; International Maritime Organization (IMO) London, UK, 1 September 2008, p. 129, 2008.

Butkovskaya, N., Kukui, A., and Le Bras, G.: $\mathrm{HNO}_{3}$ forming channel of the $\mathrm{HO}_{2}+\mathrm{NO}$ reaction as a function of pressure and temperature in the ranges of 72-600 torr and 223-323k, J. Phys. Chem. A, 111, 9047-9053, 2007.

Chen, Y., Sheng, G., Bi, X., Feng, Y., Mai, B., and Fu, J.: Emission factors for carbonaceous particles and polycyclic aromatic hydrocarbons from residential coal combustion in China, Environ. Sci. Tech., 39, 1861-1867, 2005.

Chen, Y., Zhi, G., Feng, Y., Fu, J., Feng, J., Sheng, G., and Simoneit, B. R. T.: Measurements of emission factors for primary carbonaceous particles from residential rawcoal combustion in China, Geophys. Res. Lett., 33, L20815, doi:10.1029/2006GL026966, 2006.

Charlton-Perez, C. L., Evans, M. J., Marsham, J. H., and Esler, J. G.: The impact of resolution on ship plume simulations with NOx chemistry, Atmos. Chem. Phys., 9, 7505-7518, doi:10.5194/acp-9-7505-2009, 2009.

Chipperfield, M. P., Fioletov, V. E., Bregman, B., Burrows, J., Connor, B. J., Haigh, J. D., Harris, N. R. P., Hauchecorne, A., Hood, L. L., Kawa, S. R., Krzy'scin, J. W., Logan, J. A., Muthama, N. J., Polvani, L., Randel, W. J., Sasaki, T., Stähelin, J., Stolarski, R. S., Thomason, L. W., and Zawodny, J. M.: Global Ozone, 2007: Past and Present, Chapter 3 in Scientific Assessment of Ozone Depletion: 2006, World Meteorological Organization, Geneva, Switzerland, Global Ozone Research and Monitoring Project Report No. 50, 572 pp., 2006.

Christian, T. J., Kleiss, B., Yokelson, R. J., Holzinger, R., Crutzen, P. J., Hao, W. M., Saharjo, B. H., and Ward, D. E.: Comprehensive laboratory measurements of biomass-burning emissions: 1. Emissions from Indonesian, African, and other fuels, J. Geophys. Res., 108, 4719, doi:10.1029/2003JD003704, 2003.

Clarke, L., Edmonds, J., Jacoby, H., Pitcher, H., Reilly, J., and Richels, R.: Scenarios of Greenhouse Gas Emissions and Atmospheric Concentrations, Sub-report 2.1: A of Synthesis and Assessment Product 2.1 by the US Climate Change Science Program and the Subcommittee on Global Change Research. Department of Energy, Office of Biological \& Environmental Research, Washington, DC., USA, 154 pp., 2007.

Cofala, J., Amann, M., Klimont, Z., Kupiainen, K., and HöglundIsaksson, L.: Scenarios of Global Anthropogenic Emissions of Air Pollutants and Methane until 2030, Atmos. Environ., 41, 8486-8499, doi:10.1016/j.atmosenv.2007.07.010, 2007.

Cooper, O. R., Parrish, D. D., Stohl, A., Trainer, M., Nédélec, P., Thouret, V., Cammas, J. P., Oltmans, S. J., Johnson, B. J., Tarasick, D., Leblanc, T., McDermid, I. S., Jaffe, D., Gao, R., Stith, J., Ryerson, T., Aikin, K., Campos, T., Weinheimer, A., and Avery, M. A.: Increasing springtime ozone mixing ratios in the free troposphere over western North America, Nature, 463, 344-348, doi:10.1038/nature08708, 2010.

Corbett, J. J. and Köhler, H. W.: Updated emissions from ocean shipping, J. Geophys. Res., 108, 4650, doi:10.1029/2003JD003751, 2003.

Dentener, F., Drevet, J., Lamarque, J.-F., et al.: Nitrogen and Sulphur Deposition on regional and global scales: a multimodel evaluation, Global Biogeochem. Cy., 20, GB4003,
doi:10.1029/2005GB002672, 2006.

Denman, K. L., Brasseur, G., Chidthaisong, A., Ciais, P., Cox, P. M., Dickinson, R. E., Hauglustaine, D., Heinze, C., Holland, E., Jacob, D., Lohmann, U., Ramachandran, S., da Silva Dias, P. L., Wofsy, S. C., and Zhang, X.: Couplings Between Changes in the Climate System and Biogeochemistry, in: Climate Change 2007: The Physical Science Basis. Contribution of Working Group I to the Fourth Assessment Report of the Intergovernmental Panel on Climate Change, edited by: Solomon, S., Qin, D., Manning, M., Chen, Z., Marquis, M., Averyt, K. B., Tignor, M., and Miller, H. L., Cambridge University Press, Cambridge, United Kingdom and New York, NY, USA, 2007.

Derwent, R. G., Simmonds, P. G., Manning, A. J., and Spain, T. G.: Trends over a 20-year period from 1987 to 2007 in surface ozone at the atmospheric research station, Mace Head, Ireland, Atmos. Environ., 41, 9091-9098, 2007.

Duncan, B. N., Martin, R., Staudt, A., Yevich, R., and Logan, J.: Interannual and Seasonal Variability of Biomass Burning Emissions Constrained by Satellite Observations, J. Geophys. Res., 108(D2), 4100, doi:10.1029/2002JD002378, 2003.

EMEP: Inventory Review 2006: Emission data reported to the LRTAP Convention and NEC Directive, Stage 1, 2 and 3 review, Evaluation of inventories of HMs and POPs, edited by: Vestreng, V., Rigler, E., Adams, M., et al., EMEP MSC-W, Oslo, Norway, 2006.

Endresen, Ø., Sørgård, E., Sundet, J. K., Dalsøren, S. B., Isaksen, I. S. A., Berglen, T. F., and Gravir, G.: Emission from international sea transportation and environmental impact, J. Geophys. Res., 108, 4560, doi:10.1029/2002JD002898, 2003.

Endresen, Ø., Sørgard, E., Behrens, H. L., Brett, P. O., and Isaksen, I. S. A.: A historical reconstruction of ships' fuel consumption and emissions, J. Geophys. Res., 112, D12301, doi:10.1029/2006JD007630, 2007.

Erisman, J. W., Sutton, M. A., Galloway, J., Klimont, Z., and Winiwarter, W.: How a century of ammonia synthesis changed the world, Nat. Geosci., 1(10), 636-639, 2009.

European Commission: Joint Research Centre (JRC)/Netherlands Environmental Assessment Agency (PBL), Emission Database for Global Atmospheric Research (EDGAR), release version 4.0. http://edgar.jrc.ec.europa.eu (last access: 16 February 2010), 2009.

Eyers, C. J., Addleton, D., Atkinson, K., Broomhead, M. J., Christou, R., Elliff, T., Falk, R., Gee, I., Lee, D. S., Marizy, C., Michot, S., Middel, J., Newton, P., Norman, P., Plohr, M., Raper, D., and Stanciou, N.: AERO2K global aviation emissions inventories for 2002 and 2025, QINETIQ/04/01113, 2005.

Eyring, V., Köhler, H. W., van Aardenne, J., and Lauer, A.: Emissions from International Shipping: 1. The last 50 Years, J. Geophys. Res., 110, D17305, doi:10.1029/2004JD005619, 2005.

Eyring, V., Isaksen, I. S. A., Berntsen, T., Collins, W. J., Corbett, J. J., Endresen, O., Grainger, R. G., Moldanova, J., Schlager, H., and Stevenson, D. S.: Transport impacts on atmosphere and climate: Shipping, Atmos. Environ., doi:10.1016/j.atmosenv.2009.04.059, in press, 2010.

FAO (Food and Agriculture Organization): WRB (World Reference Base) Map of World Soil Resources. Land and Water Development Division AGL, http://www.fao.org/ag/agl/agll/wrb/soilres. stm, last access: 16 February 2010, Food and Agriculture Organization of the United Nations, Rome, Italy, 2003. 
Fernandes, S. M., Trautmann, N. M., Streets, D. G., Roden, C. A., and Bond, T. C.: Global biofuel use, 1850-2000, Global Biogeochem. Cy., 21, GB2019, doi:10.1029/2006GB002836, 2007.

Franke, K., Eyring, V., Sander, R., Hendricks, J., Lauer, A., and Sausen, R.: Toward Effective Emissions of Ships in Global Models, Meteorol. Z., 17(2), 117-129, 2008.

Fujino, J., Nair, R., Kainuma, M., Masui, T., and Matsuoka, Y.: Multigas mitigation analysis on stabilization scenarios using AIM global model, Multigas Mitigation and Climate Policy, The Energy Journal Special Issue, 343-354, 2006.

Garg, A., Shukla, P. R., and Kapshe, M.: The sectoral trends of multigas emissions inventory of India, Atmos. Environ. 40, 4608-4620, 2006.

Gauss, M., Myhre, G., Isaksen, I. S. A., Grewe, V., Pitari, G., Wild, O., Collins, W. J., Dentener, F. J., Ellingsen, K., Gohar, L. K., Hauglustaine, D. A., Iachetti, D., Lamarque, F., Mancini, E., Mickley, L. J., Prather, M. J., Pyle, J. A., Sanderson, M. G., Shine, K. P., Stevenson, D. S., Sudo, K., Szopa, S., and Zeng, G.: Radiative forcing since preindustrial times due to ozone change in the troposphere and the lower stratosphere, Atmos. Chem. Phys., 6, 575-599, doi:10.5194/acp-6-575-2006, 2006.

Gent, P. R., Yeager, S. G., Neale, R. B., Levis, S., and Bailey, D. A.: Improvements in a half degree atmosphere/land version of the CCSM, Clim. Dynam., 79, 25-58, doi:10.1007/s00382-0090614-8, 2009.

Goldewijk, K.: Three centuries of global population growth: A spatial referenced population density database for 1700 2000, available at http://www.mnp.nl/edgar/model/edgarv32/ v32ftmaps/ (last access: 16 February 2010), Popul. Environ., 26(5), 343-367, 2005.

Hanson, D. and Mauersberger, K.: Laboratory studies of the nitric acid tridydrate: Implications for the south polar stratosphere, Geophys. Res. Lett., 15, 855-858, 1988.

Heil, A.: Indonesian Forest and Peat Fires: Emissions, Air Quality, and Human Health, Berichte zur Erdsystemforschung, 34, MaxPlanck-Institute for Meteorology, Hamburg, Germany, 2007.

Hijioka, Y., Matsuoka, Y., Nishimoto, H., Masui, M., and Kainuma, M.: Global GHG emissions scenarios under GHG concentration stabilization targets, J. Global Environ. Eng., 13, 97-108, 2008.

Holben, B. N., Eck, T. F., Slutsker, I., et al.: AERONET-A Federated Instrument Network and Data Archive for Aerosol Characterization, 1998.

Horowitz, L. W., Walters, S., Mauzerall, D. L., Emmons, L. K., Rasch, P. J., Granier, C., Tie, X. X., Lamarque, J.-F., Schultz, M. G., Tyndall, G. S., Orlando, J. J., and Brasseur, G. P.: A global simulation of tropospheric ozone and related tracers: Description and evaluation of MOZART, version 2, J. Geophys. Res., 108(D24), 4784, doi:10.1029/2002JD002853, 2003.

Houweling, S., Dentener, F., and Lelieveld, J.: The impact of non-methane hydrocarbon compounds on tropospheric photochemistry, J. Geophys. Res., 103, 10673-10696, doi:10.1029/97JD03582, 1998.

Iinuma, Y., Brueggemann, E., Gnauk, T., Mueller, K., Andreae, M. O., Helas, G., Parmar, R., and Herrmann, H.: Source characterization of biomass burning particles: The combustion of selected European conifers, African hardwood, savanna grass, and German and Indonesian peat, J. Geophys. Res., 112, 8209, doi:10.1029/2006JD007120, 2007.

Ito, A. and Penner, J. E.: Historical emissions of carbona- ceous aerosols from biomass and fossil fuel burning for the period 1870-2000, Global Biogeochem. Cy., 19, GB2028, doi:10.1029/2004GB002374, 2005.

Johnson, M., Edwards, R., Frenk, C. A., and Masera, O.: Infield greenhouse gas emissions from cookstoves in rural Mexican households, Atmos. Environ., 42, 1206-1222, 2008.

Junker, C. and Liousse, C.: A global emission inventory of carbonaceous aerosol from historic records of fossil fuel and biofuel consumption for the period 18601997, Atmos. Chem. Phys., 8, 1195-1207, doi:10.5194/acp-8-1195-2008, 2008.

Kasischke, E. S., Hyer, E. J., Novelli, P. C., Bruhwiler, L. P., French, N. H. F., Sukhinin, A., Hewson, J. H., and Stocks, B. J.: Influences of boreal fire emissions on Northern Hemisphere atmospheric carbon and carbon monoxide. Global Biogeochem. Cy., 19, GB1012, doi:10.1029/2004GB002300, 2005.

Kinnison, D. E., Brasseur, G. P., Walters, S., et al.: Sensitivity of Chemical Tracers to Meteorological Parameters in the MOZART-3 Chemical Transport Model, J. Geophys. Res., 112, D20302, doi:10.1029/2006JD007879, 2007.

Klimont, Z., Cofala, J., Xing, J., Wei, W., Zhang, C., Wang, S., Kejun, J., Bhandari, P., Mathura, R., Purohit, P., Rafaj, P., Chambers, A., Amann, M., and Hao, J.: Projections of $\mathrm{SO}_{2}, \mathrm{NO}_{\mathrm{x}}$, and carbonaceous aerosols emissions in Asia, Tellus, 61B, 602-617, doi:10.1111/j.1600-0889.2009.00428.x, 2009.

Klimont, Z. and Streets, D. G.: Emissions inventories and projections for assessing hemispheric or intercontinental transport, in: Hemispheric transport of air pollution 2007, edited by: Keating, T. and Zuber, A., United Nations, Geneva, Atmospheric Pollution Studies No. 16, ECE/EB.AIR/94, 2007.

Lack, D., Lerner, B., Granier, C., Baynard, T., Lovejoy, E., Massoli, P., Ravishankara, A. R., and Williams, E.: Light absorbing carbon emissions from commercial shipping, Geophys. Res. Let., 35, L13815, doi:10.1029/2008GL033906, 2008.

Lamarque, J.-F., Hess, P., Emmons, L., Buja, L., Washington, W., and Granier, C.: Tropospheric ozone evolution between 1890 and 1990, J. Geophys. Res., 110(D8), D08304, doi:10.1029/2004JD005537, 2005.

Lamarque, J.-F., Kinnison, D. E., Hess, P. G., and Vitt, F.: Simulated lower stratospheric trends between 1970 and 2005: identifying the role of climate and composition changes, J. Geophys. Res., 113, D12301, doi:10.1029/2007JD009277, 2008.

Lavoué, D., Liousse, C., Cachier, H., and Goldammer, J.: Carbonaceous aerosol source inventory for temperate and boreal fires, J. Geophys. Res., 105, 26871-26890, 2000.

Lecht, M.: Comparison of DLR Fuel Flow Method and the P3-T3 Method for Cruise EINOX Prediction, ICAO/CAEP/WG3 Alternative Emissions Methodology Task Group, Boeing, Seattle, USA, 22-23 September, 1999.

Lee, D. S., Owen, B., Graham, A., Fichter, C., Lim, L. L., and Dimitriu, D.: Allocation of International aviation emissions from scheduled air traffic - present day and historical (Report 2 of 3), Manchester Metropolitan University, Centre for Air Transport and the Environment, http://www.cate.mmu.ac.uk/documents/ projects/mmuallocationsreport2currentdayv1_5.pdf last access: (16 February 2010), Manchester, UK, CATE-2005-3(C)-2, 2005.

Lelieveld, J., van Aardenne, J., Fischer, H., de Reus, M., Williams, J., and Winkler, P: Increasing Ozone over the Atlantic Ocean, Science, 304, 1483, doi:10.1126/science.1096777, 2004.

Liao, H., Adams, P. J., Ching, S. H., et al.: Interactions be- 
tween tropospheric chemistry and aerosols in a unified general circulation model, J. Geophys. Res., 108(D1), 4001, doi:10.1029/2001JD001260, 2003.

Mahowald, N., Muhs, D. R., Levis, S., et al.: Change in atmospheric mineral aerosols in response to climate: last glacial period, preindustrial, modern and doubled-carbon dioxide climates, J. Geophys. Res., 111, D10202, doi:10210.11029/12005JD006653, 2006a.

Mahowald, N., Lamarque, J.-F., Tie, X. X., and Wolff, E.: Sea salt aerosol response to climate change: last glacial maximum, pre-industrial,and doubled-carbon dioxide climates, J. Geophys. Res., 111, D05303, doi:10.1029/2005JD006459, 2006 b.

Mahowald, N., Engelstaeder, S., Luo, C., et al.: Atmospheric Iron deposition: Global distribution, variability and human perturbations, Annu. Rev. Mar. Sci., 1, 245-278, doi:210.1146/annurev/marine.010908.163727, 2009.

Marlon, J. R., Bartlein, P. J., Carcaillet, C., Gavin, D. G., Harrison, S. P., Higuera, P. E., Joss, F., Power, M. J., and Prentice, I. C.: Climate and human influences on global biomass burning over the past two millenia, Nat. Geosci., 1, 697-702, doi:10.1038/ngeo313, 2008.

McConnell, J. R., Edwards, R., Kok, G. L., Flanner, M. G., Zender, C. S., Saltzman, E. S., Banta, J. R., Pasteris, D. R., Carter, M. M., and Kahl, J. D. W.: 20th Century industrial black carbon emissions altered Arctic climate forcing, Science, 317, 5843, doi:10.1126/science.1144856, 2007.

Meehl, G. A., Stocker, T. F., Collins, W. D., Friedlingstein, P., Gaye, A. T., Gregory, J. M., Kitoh, A., Knutti, R., Murphy, J. M., Noda, A., Raper, S. C. B., Watterson, I. G., Weaver, A. J., and Zhao, Z.-C.: Global Climate Projections, in: Climate Change 2007: The Physical Science Basis, Contribution of Working Group I to the Fourth Assessment Report of the Intergovernmental Panel on Climate Change, edited by: Solomon, S., Qin, D., Manning, M., Chen, Z., Marquis, M., Averyt, K. B., Tignor, M., and Miller, H. L., Cambridge University Press, Cambridge, UK and New York, NY, USA, 2007.

Metzger, S., Dentener, F., Pandis, S., and Lelieveld, J.: Gas/aerosol partitioning: 1. A computationally efficient model, J. Geophys. Res., 107(D16), 4312, doi:10.1029/2001JD001102, 2002.

Mieville, A., Granier, C., Liousse, C., Guillaume, B., Mouillot, F., Lamarque, J.-F., Grégoire, J.-M., and Pétron, G.: Emissions of gases and particles from biomass burning using satellite data and an historical reconstruction, Atmos. Environ., 44, 1469-1477, doi:10.1016/j.atmosenv.2010.01.011, 2010.

Moss, T., Babiker, M., Brinkman, S., Calvo, E., Carter, T., Edmonds, J., Elgizouli, I., Emori, S., Erda, L., Hibbard, K., Jones, R., Kainuma, M., Kelleher, J., Lamarque, J.-F., Manning, M., Matthews, B., Meehl, G., Meyer, L., Mitchell, J., Nakic'enovic', N., O’Neill, B., Pichs, T., Riahi, K., Rose, S., Runci, P., Stouffer, R., van Vuuren, D., Weyant, J., Wilbanks, T., van Ypersele, J. P., and Zurek, M.: Towards New Scenarios for Analysis of Emissions, Climate Change, Impacts, and Response Strategies, available at: http://www.aimes.ucar.edu/docs/, last access: 16 February 2010, Intergovernmental Panel on Climate Change, Geneva, 132 pp., 2008.

Mouillot, F. and Field, C. B.: Fire history and the global carbon budget: a $1^{\circ} \times 1^{\circ}$ fire history reconstruction for the 20th century, Glob. Change Biol., 11, 398-420, doi:10.1111/j.13652486.2005.00920.x, 2005.
NARSTO: Improving emission inventories for effective air quality management across North America, NARSTO, http://www. narsto.org/section.src?SID=8 (last access: 16 Feburary 2010), 2006.

Ohara, T., Akimoto, H., Kurokawa, J., Horii, N., Yamaji, K., Yan, X., and Hayasaka, T.: An Asian emission inventory of anthropogenic emission sources for the period 1980-2020, Atmos. Chem. Phys., 7, 4419-4444, doi:10.5194/acp-7-4419-2007, 2007.

Olivier, J. G. J., Bouwman, A. F., Van der Maas, C. W. M., Berdowski, J. J. M., Veldt, C., Bloos, J. P. J., Visschedijk, A. J. H., Zandveld, P. Y. J., and Haverlag, J. L.: Description of EDGAR Version 2.0, A set of global emission inventories of greenhouse gases and ozone-depleting substances for all anthropogenic and most natural sources on a per country basis and on $1 \times 1$ degree grid, RIVM/TNO report, 1996 .

Olivier, J. G. J., Van Aardenne, J. A., Dentener, F., Ganzeveld, L., Peters, J. A. H. W., et al.: Recent trends in global greenhouse gas emissions: regional trends and spatial distribution of key sources, in: Non- $\mathrm{CO}_{2}$ Greenhouse Gases (NCGG-4), coordinator: van Amstel, A., Millpress, Rotterdam, ISBN 905966043 9, 325-330, 2005.

Oltmans, S. J., Lefohn, A. S., Harris, J. M., et al.: Long-term changes in tropospheric ozone, Atmos. Environ., 40, 3156-3173, 2006.

Page, S. E., Siegert, F., Rieley, J. O., Boehm, H.-D. V., Jaya, A., and Limin, S.: The amount of carbon release from peat and forest fires in Indonesia during 1997, Nature, 420, 61-65, 2002.

Parashar, D. C., Gadi, R., Mandal, T. K., and Mitra, A. P.: Carbonaceous aerosol emissions from India, Atmos. Environ., 39, 7861-7871, 2005.

Parrish, D. D.: Critical evaluation f US on-road vehicle emission inventories, Atmos. Environ., 40, 2288-2300, 2006

Parrish, D. D., Dunlea, E. J., Atlas, E. L., et al.: Changes in the photochemical environ- ment of the temperate North Pacific troposphere in response to increased Asian emissions, J. Geophys. Res., 109, D23S18, doi:10.1029/2004JD004978, 2004.

Petzold, A., Hasselbach, J., Lauer, P., Baumann, R., Franke, K., Gurk, C., Schlager, H., and Weingartner, E.: Experimental studies on particle emissions from cruising ship, their characteristic properties, transformation and atmospheric lifetime in the marine boundary layer, Atmos. Chem. Phys., 8, 2387-2403, doi:10.5194/acp-8-2387-2008, 2008.

Prather, M. J.: Numerical advection by conservation of secondorder moments, J. Geophys. Res., 91, 6671-6681, 1986.

Randerson, J. T., van der Werf, G. R., Collatz, G .J., Giglio, L., Still, C. J., Kasibhatla, P., Miller, J. B., White, J. W. C., DeFries, R. S., and Kasischke, E. S.: Fire emissions from C3 and $\mathrm{C} 4$ vegetation and their influence on interannual variability of atmospheric $\mathrm{CO}_{2}$ and $\mathrm{d}^{13} \mathrm{CO}_{2}$, Global Biogeochem. Cy., 19, GB2019, doi:10.1029/2004GB002366, 2005.

Rayner, N. A., Parker, D. E., Horton, E. B., Folland, C. K., Alexander, L. V., Rowell, D. P., Kent, E. C., and Kaplan, A.: Global analyses of sea surface temperature, sea ice, and night marine air temperature since the late nineteenth century, J. Geophys. Res., 108(D14), 4407, doi:10.1029/2002JD002670, 2003.

Riahi, K., Gruebler, A., and Nakicenovic, N.: Scenarios of long-term socioeconomic and environmental development under climate stabilization. Greenhouse Gases - Integrated Assess- 
ment, Special Issue, Technol. Forecast. Soc., 74(7), 887-935, doi:10.1016/j.techfore.2006.05.026, 2007.

Richter, A., Burrows, J. P., Nuss, H., Granier, C., and Niemeier, U.: Increase in tropospheric nitrogen dioxide over China observed from space, Nature, 437(7055), 129-132, 2005.

Roden, C. A., Bond, T. C., Conway, S., and Pinel, A. B. O.: Emission factors and real-time optical properties of particles emitted from traditional wood burning cookstoves, Environ. Sci. Technol., 40, 6750-6757, 2006.

Roden, C. A., Bond, T. C., Conway, S., Pinel, A. B. O., MacCarty, N., and Still, D.: Laboratory and field investigations of particulate and carbon monoxide emissions from traditional and improved cookstoves, Atmos. Environ., 43, 1170-1181, 2009.

Sander, S. P., Friedl, R. R., DeMore, W. B., et al: Chemical kinetics and photochemical data for use in stratospheric modeling, eval. 13, JPL publ. 00-003, 2000.

Sander S. P., R. R. Friedl, A. R. Ravishankara, et al.: Chemical Kinetics and Photochemical Data for Use in Atmospheric Studies Evaluation Number 15, Publication 06-2, Jet Propulsion Laboratory, Pasadena, CA, 2006.

Sausen, R. and Schumann, U.: Estimates of the climate response to aircraft $\mathrm{CO}_{2}$ and $\mathrm{NO}_{\mathrm{x}}$ emissions scenarios, Climatic Change, 44, 27-58, 2000.

Schmidt, G. A., Ruedy, R., Hansen, J. E., Aleinov, I., Bell, N., Bauer, M., Bauer, S., Cairns, B., Canuto, V., Cheng, Y., Del Genio, A., Faluvegi, G., Friend, A. D., Hall, T. M., Hu, Y., Kelley, M., Kiang, N. Y., Koch, D., Lacis, A. A., Lerner, J., Lo, K. K., Miller, R. L., Nazarenko, L., Oinas, V., Perlwitz, J., Perlwitz, J., Rind, D., Romanou, A., Russell, G. L., Sato, M., Shindell, D. T., Stone, P. H., Sun, S., Tausnev, N., Thresher, D., and Yao, M.-S.: Present day atmospheric simulations using giss modele: Comparison to in-situ, satellite and reanalysis data, J. Climate, 19, 153-192, 2006.

Schultz, M. and Rast, S.: Emission datasets and methodologies for estimating emissions, available at: http://retro.enes.org (last access: 16 February 2010), RETRO Report D1-6,, 2007.

Schultz, M. G., Heil, A., Hoelzemann, J. J., Spessa, A., Thonicke, K., Goldammer, J., Held, A. C., Pereira, J. M., and van het Bolscher, M.: Global Wildland Fire Emissions from 1960 to 2000, Global Biogeochem. Cyc., 22, GB2002, doi:10.1029/2007GB003031, 2008.

Shindell, D. T., Faluvegi, G., Stevenson, D. S., et al., Multi-model simulations of carbon monoxide: Comparison with observations and projected near-future changes, J. Geophys. Res., 111, D19306, doi:10.1029/2006JD007100, 2006a.

Shindell, D. T., Faluvegi, G., Unger, N., Aguilar, E., Schmidt, G. A., Koch, D. M., Bauer, S. E., and Miller, R. L.: Simulations of preindustrial, present-day, and 2100 conditions in the NASA GISS composition and climate model G-PUCCINI, Atmos. Chem. Phys., 6, 4427-4459, doi:10.5194/acp-6-4427-2006, $2006 \mathrm{~b}$.

Shindell, D. T., Chin, M., Dentener, F., Doherty, R. M., Faluvegi, G., Fiore, A. M., Hess, P., Koch, D. M., MacKenzie, I. A., Sanderson, M. G., Schultz, M. G., Schulz, M., Stevenson, D. S., Teich, H., Textor, C., Wild, O., Bergmann, D. J., Bey, I., Bian, H., Cuvelier, C., Duncan, B. N., Folberth, G., Horowitz, L. W., Jonson, J., Kaminski, J. W., Marmer, E., Park, R., Pringle, K. J., Schroeder, S., Szopa, S., Takemura, T., Zeng, G., Keating, T. J., and Zuber, A.: A multi-model assessment of pollu- tion transport to the Arctic, Atmos. Chem. Phys., 8, 5353-5372, doi:10.5194/acp-8-5353-2008, 2008.

Sinha, P., P.V. Hobbs, R.J. Yokelson, T.J. Christian, T.W. Kirchstetter, and R. Bruintjes, Emissions of trace gases and particles from two ships in the southern Atlantic Ocean, Atmos. Environ., 37, 2139-2148, 2003

Simos, D.: PIANO: PIANO User's Guide Version 4.0, Lissys Limited, UK www.piano.aero (last access: 16 February 2010), 2004.

Smith, S. J., Steven, J., Pitcher, H., and Wigley, T. M. L.: Global and Regional Anthropogenic Sulfur Dioxide Emissions, Global Planet. Change, 29(1-2), 99-119, 2001.

Smith, S. J., Andres, R., Conception, E., and Lurz, J.: Historical Sulfur Dioxide Emissions 1850-2000: Methods and Results, PNNL Research Report, Joint Global Change Research Institute, 8400 Baltimore Avenue College park, Maryland, 20740, 2004.

Smith, S. J., van Aardenne, J., Klimont, Z., Andres, R., Volke, A., and Delgado Arias, S.: Anthropogenic sulfur dioxide emissions: 18502005, Atmos. Chem. Phys. Discuss., 10, 1611116151, doi:10.5194/acpd-10-16111-2010, 2010.

Stevenson, D. S., Dentener, F. J., Schultz, M. G., et al. Multi-model ensemble simulations of present-day and nearfuture tropospheric ozone, J. Geophys. Res., 111, D08301, doi:10.1029/2005JD006338, 2006

Streets, D. G., Bond, T. M. L., Carmichael, G. R., Fernandes, S., Fu, Q., He, D., Klimont, Z., Nelson, S. M., Tsai, N. Y., Wang, M. Q., Woo, J.-H., and Yarber, K. F.: An inventory of gaseous and primary aerosol emissions in Asia in the year 2000. J. Geophys. Res., 108(D21), 8809, doi:10.1029/2002JD003093, 2003.

Streets, D. G., Zhang, Q., Wang, L., He, K., Hao, J., et al.: Revisiting China's $\mathrm{CO}$ emissions after the Transport and Chemical Evolution over the Pacific (TRACE-P) mission: Synthesis of inventories, atmospheric modeling, and observations, J. Geophys. Res., 111, 1-16, 2006.

Taylor, K. E., Stouffer, R. J., and Meehl, G. A.: A Summary of the CMIP5 Experiment Design, https://cmip.llnl.gov/cmip5/docs/ Taylor_CMIP5_design.pdf (last access: 26 July 2010), 2009.

Tie, X. X., Brasseur, G. P., Emmons, L. K., et al.: Effects of aerosols on tropospheric oxidants: A global model study, J. Geophys. Res., 106, 2931-2964, 2001.

Tie, X. X., Madronich, S., Walters, S., et al.: Assessment of the global impact of aerosols on tropospheric oxidants, J. Geophys. Res., 110(D3), D03204, doi:10.1029/2004JD005359, 2005.

US Environmental Protection Agency: Compilation of air pollutant emission factors, US Environmental Protection Agency, Research Triangle Park, NC, 1996.

US Environmental Protection Agency: SPECIATE 4.0: Speciation database development documentation, US Environmental Protection Agency, Research Triangle Park, NC, 2006.

Van Aardenne, J. A., Dentener, F. J., Olivier, J. G. J., Klein Goldewijk, C. G. M., and Lelieveld, J.: A $1 \times 1$ degree resolution dataset of historical anthropogenic trace gas emissions for the period 1890-1990, Global Biogeochem. Cy., 15(4), 909-928, 2001.

Van Aardenne, J. A., Dentener, F., Olivier, J. G. J., and Peters, J. A. H. W.: The EDGAR 3.2 Fast Track 2000 dataset (32FT2000), http://www.mnp.nl/edgar/model/v32ft2000edgar/ docv32ft20 (last access: 16 February 2010), 2005.

van der Werf, G. R., Randerson, J. T., Giglio, L., Collatz, G. J., Kasibhatla, P. S., and Arellano Jr., A. F.: Interannual variabil- 
ity in global biomass burning emissions from 1997 to 2004, Atmos. Chem. Phys., 6, 3423-3441, doi:10.5194/acp-6-3423-2006, 2006.

Van Vuuren, D. P., Eickhout, B., Lucas, P. L., and den Elzen, M. G. J.: Long-term multi-gas scenarios to stabilise radiative forcing - Exploring costs and benefits within an integrated assessment framework, Multigas Mitigation and Climate Policy, The Energy Journal, Special Issue, 2006.

Van Vuuren, D. P., den Elzen, M. G. J., Lucas, P. L., Eickhout, B., Strengers, B. J., van Ruijven, B., Wonink, S., and van Houdt, R.: Stabilizing greenhouse gas concentrations at low levels: an assessment of reduction strategies and costs, Climatic Change, 81, 119-159, 2007.

Venkataraman, C., Habib, G., Eiguren-Fernandez, A., Miguel, A. H., and Friedlander, S. K.: Residential biofuels in South Asia: carbonaceous aerosol emissions and climate impacts, Science, 307, 1454-1456, 2005.

Vestreng, V., Adams, M., and Goodwin, J.: Inventory review 2004, EMEP Techincal Report MSC-W1/2004, 2004.

Volckens, J., Olson, D. A., and Hays, M. D.: Carbonaceous species emitted from handheld two-stroke engines, Atmos. Environ., 42, 1239-1248, 2008.
Volz, A. and Kley, D.: Ozone Measurements in the 19th Century: An Evaluation of the Montsouris Series, Nature, 332, 240-242, 1988.

Wang, C., Corbett, J. J., and Firestone, J.: Improving Spatial Representation of Global Ship Emissions Inventories, ES\&T, 42, 193 199, doi:10.1021/es0700799, 2007.

Yan, X., Akimoto, H., and Ohara, T.: Statistical modeling of NOx emission from global soils, Global Biogeochem. Cy., 19, GB3019, doi:10.1029/2004GB002276, 2005.

Yevich, R. and J. A. Logan, An assesment of biofuel use and burning of agricultural waste in the developing world, Global Biogeochem. Cy., 17(4), 1095, doi:10.1029/2002GB001952, 2003.

Zhang, Q., Streets, D. G., Carmichael, G. R., He, K. B., Huo, H., Kannari, A., Klimont, Z., Park, I. S., Reddy, S., Fu, J. S., Chen, D., Duan, L., Lei, Y., Wang, L. T., and Yao, Z. L.: Asian emissions in 2006 for the NASA INTEX-B mission, Atmos. Chem. Phys., 9, 5131-5153, doi:10.5194/acp-9-5131-2009, 2009.

Zhi, G., Chen, Y., Feng, Y., Xiong, S., Li, J., Zhang, G., Sheng, G., and Fu, J.: Emission characteristics of carbonaceous particles from various residential coal-stoves in China, Environ. Sci. Technol., 42, 3310-3315, 2008. 